\title{
Temporal gene profiling of the 5XFAD transgenic mouse model highlights the importance of microglial activation in Alzheimer's disease
}

Véréna Landel ${ }^{1 *}$, Kévin Baranger ${ }^{1,2}$, Isabelle Virard ${ }^{1}$, Béatrice Loriod ${ }^{3,4}$, Michel Khrestchatisky ${ }^{1}$, Santiago Rivera ${ }^{1}$, Philippe Benech ${ }^{1+}$ and François Féron ${ }^{1+}$

\begin{abstract}
Background: The 5XFAD early onset mouse model of Alzheimer's disease (AD) is gaining momentum. Behavioral, electrophysiological and anatomical studies have identified age-dependent alterations that can be reminiscent of human AD. However, transcriptional changes during disease progression have not yet been investigated. To this end, we carried out a transcriptomic analysis on RNAs from the neocortex and the hippocampus of 5XFAD female mice at the ages of one, four, six and nine months (M1, M4, M6, M9).

Results: Our results show a clear shift in gene expression patterns between M1 and M4. At M1, 5XFAD animals exhibit region-specific variations in gene expression patterns whereas M4 to M9 mice share a larger proportion of differentially expressed genes (DEGs) that are common to both regions. Analysis of DEGs from M4 to M9 underlines the predominance of inflammatory and immune processes in this AD mouse model. The rise in inflammation, sustained by the overexpression of genes from the complement and integrin families, is accompanied by an increased expression of transcripts involved in the NADPH oxidase complex, phagocytic processes and IFN- $\gamma$ related pathways.

Conclusions: Overall, our data suggest that, from M4 to M9, sustained microglial activation becomes the predominant feature and point out that both detrimental and neuroprotective mechanisms appear to be at play in this model. Furthermore, our study identifies a number of genes already known to be altered in human AD, thus confirming the use of the 5XFAD strain as a valid model for understanding AD pathogenesis and for screening potential therapeutic molecules.
\end{abstract}

Keywords: Transcriptome, Hippocampus, Neocortex, Neuro-immune processes, Inflammation, Interferon, Oxidative stress, GTPase signaling, Microglia, Phagocytosis

\section{Background}

Significant progress has been made uncovering the role of specific genes in Alzheimer's disease (AD), yet little is known about the global molecular changes leading to neurodegeneration and brain dysfunction. One drawback comes from the fact that brain tissue from AD patients only becomes available post mortem, i.e. at very late stages of the disease. For this reason, transgenic AD mouse models are precious tools to gain insight into the

\footnotetext{
* Correspondence: verena.landel@univ-amu.fr

${ }^{\dagger}$ Equal contributors

${ }^{1}$ Aix Marseille Université, CNRS, NICN UMR 7259, 13916 Marseille, France Full list of author information is available at the end of the article
}

spatio-temporal changes that may affect molecular cascades involved in disease progression.

The 5XFAD mouse model used in this study bears five mutations linked to familial forms of $\mathrm{AD}$ and recapitulates in a few months the main features of $\mathrm{AD}$ [1]. All these mutations act in an additive manner to boost the production of $\beta$-amyloid $(A \beta)$ peptides, resulting from the processing of amyloid precursor protein (APP), in particular the 42 amino acid form, A 342 [2-6]. Compared with other models, 5XFAD mice display AD features much earlier. Though they do not present a clear tau pathology, they develop cerebral amyloid plaques and gliosis as early as 2 months of age [1]. Electrophysiological studies 
detected hippocampal synaptic dysfunctions in M6 5XFAD animals, concomitant with synaptic loss and memory deficits [7-22]. Progressive neuronal death has been described from M9 onwards in cortical layer 5 neurons and subiculum of 5XFAD mice [12,23], a characteristic that is absent in most AD mouse models.

How these pathophysiological alterations correlate with global spatio-temporal changes in gene expression remains to be thoroughly evaluated. Few prior transcriptomic studies examined AD mouse models, usually at a single time point or in a single brain region [24-29]. Only two studies investigated the transcriptome of 5XFAD mice, one using RNA-seq in frontal cortex and cerebellum of 7 week-old transgenic mice [30], the other using whole-brain next-generation sequencing to compare young (M3-6) versus old (M12) mice from 5XFAD and Tg4-42 strains [31].

Here, we carried out a longitudinal transcriptomic study on two major brain regions affected in $\mathrm{AD}$, the hippocampus and the neocortex, obtained from 5XFAD female mice at presymptomatic (M1), prodromal-like (M4) and symptomatic stages (M6 and M9) of the pathology. We investigated how genes with a modulated expression are involved in functional networks through the use of two text-mining based softwares (Ingenuity and PredictSearch). Among the genes involved in these networks, a bibliographic search was performed to identify those reported in $\mathrm{AD}$ patients.

Our results indicate a tremendous shift in the transcriptional profile between M1 and M4 in both the cortex and hippocampus of 5XFAD mice, mainly characterized by an increase in inflammatory and immune markers. Moreover, they emphasize the predominant activation of microglia and transcriptional activities induced by interferon- $\gamma$ (IFN- $\gamma)$, likely through the expression of interferon regulatory factor 8 (IRF8), which stands out as a key transcriptional regulator in our study. The main IRF8 target pathways include antigen processing, antigen presentation and phagosome maturation, associated with a modulation of GTPase signaling. Interestingly, a high number of dysregulated genes are associated to $\mathrm{AD}$, confirming that the 5XFAD model mirrors, at an early age, many aspects of this neurodegenerative disease.

\section{Results and discussion}

Temporal distribution of dysregulated genes reveals dramatic changes from M4 onwards

Figure 1 summarizes the global screening of gene expression analysis of cortex and hippocampus from 5XFAD compared with wild type mice at M1, M4, M6 and M9. The number of differentially expressed genes (DEGs) increases with age in both tissues (Figure 1A) with a drastic increase between M4 and M6 when considering the number of up- and down-regulated genes (Figure $1 \mathrm{~A}$ and $\mathrm{B}$ ).

At M1, twice as many genes are dysregulated in the hippocampus as in the cortex (Figure 1A), suggesting that distinct alterations occur in these two regions at that early stage, as described at the histological level [1]. Additionally, we observed many shared DEGs between cortex and hippocampus (Figure 1B), in particular at M4, when nearly $50 \%$ of the DEGs are common to both brain regions. By contrast, at $\mathrm{M} 1$, only $12 \%$ of the genes modulated in hippocampus overlap with those found in cortex (Figure 1B).

In order to evaluate the specificities at each studied stage, we looked at overlapping and non-overlapping DEGs in transgenic animals, from M1 to M9, separately in cortex and hippocampus. Interestingly, the expression of only 23 genes from the cortex and 55 from the hippocampus (Figure $1 \mathrm{C}$ and $\mathrm{D}$, white areas) is modulated across all ages (Additional file 1: Table S1). Strikingly, the expression of an important number of genes (293 for the cortex; 278 for the hippocampus; Figure 1C and D, light orange areas) is altered through M4 to M9. Among those, 183 DEGs at M4, M6 and M9 are common to both tissues (Additional file 2: Table S2). Most of these genes are upregulated; only 3 of these DEGs show decreased expression at all three ages and in both regions, while 176 display an increased expression and 4 are inconsistently either up- or down-regulated in cortex or hippocampus (Additional file 2: Table S2).

\section{DEG-related functions support alterations in inflammation pathways and behavior}

To investigate whether these quantitative changes might reflect alterations of specific processes and/or pathways contributing to disease progression, we looked at the most upregulated genes in both tissues over time (Figure 2) using Ingenuity Pathway Analysis (IPA). Six out of the top ten upregulated genes from the cortex and four from the hippocampus at M4 also appear among the top ten upregulated genes at M6 and M9 (Figure 2). Inflammation and immunomodulation are the main affected processes in these tissues, as illustrated by changes in expression of Clec7a (coding for the dectin-1 protein), Cst7 (cystatin F), Itgax $(\mathrm{Cd} 11 \mathrm{c})$ and genes encoding chemokines $\mathrm{Ccl} 3, \mathrm{Ccl} 4$, Ccl6 and the glial fibrillary acidic protein (Gfap) (Table 1).

In contrast to these overlaps, the top ten upregulated genes in M1 animals are fundamentally distinct from those found in older animals (Figure 2). Only the transthyretin (Ttr) gene, encoding a transporter of thyroxin and retinol, is strongly upregulated in the cortex at both M1 and M4 (Figure 2). Ttr, previously identified as upregulated in the frontal cortex of young, presymptomatic 5XFAD mice [30,31], is able to bind and sequester $A \beta$ peptide, thereby preventing its aggregation and plaque 


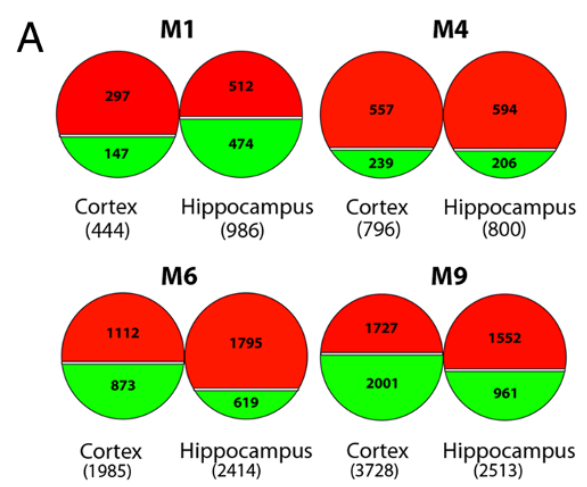

B
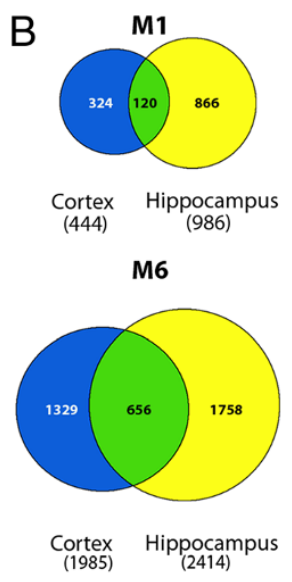

D

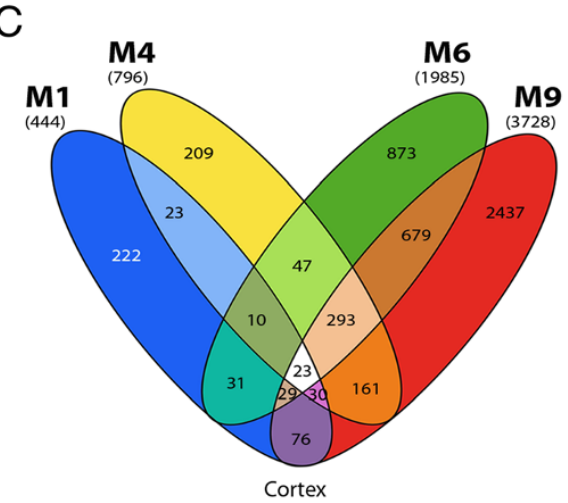

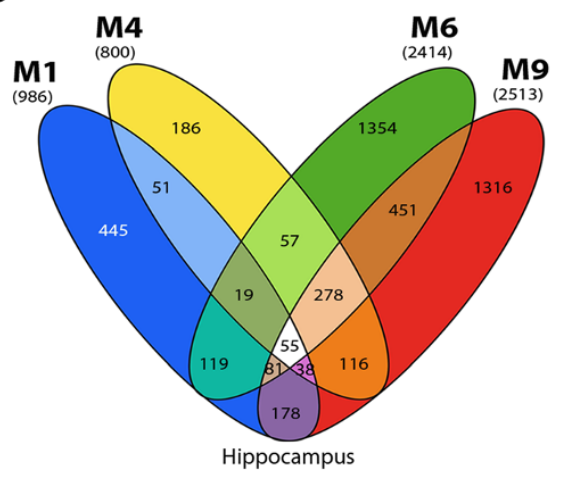

Figure 1 Overview of gene expression profiles in cortex and hippocampus of 5XFAD mice, at 4 different ages, reveals a shift in expression patterns between M1 and M4. (A) Number of up- (red) and down- (green) regulated genes in cortex and hippocampus of 5XFAD mice compared with wild type animals at M1, M4, M6 and M9. Total number of DEGs for each brain region at each age is reported in brackets. (B) Number of overlapping and non-overlapping DEGs in cortex (blue) and hippocampus (yellow) at M1, M4, M6 and M9. The center of the Venn diagram (green) illustrates the proportion of shared DEGs between both brain regions. (C and D) Number of shared and specific DEGs across all ages in cortex (C) and hippocampus (D). Analysis was based on the total number of DEGs, both up- and down-regulated at each age. Fold change (FC) cut-off used for above analyses was -1.5 > FC > 1.5 when comparing signals from 5XFAD mice with wild type controls.

formation [32-34]. The finding that high levels of Ttr precede plaque deposition is corroborated by another study performed on Tg2576 transgenic mice, a model in which plaque deposition does not occur until M12 [35]. Moreover, Ttr was identified as a physiological target of APP, since its expression is increased by soluble extracellular APP processed products [34]. Interestingly, Klotho (Kl), encoding a hormone involved in aging processes such as oxidative stress and calcium homeostasis [36-38], was similarly dysregulated. Both genes exhibit a similar expression profile in our transcriptomic study (Table 1), confirming that Ttr and $K l$ are co-regulated APP targets. In the cortex, their expression decreases progressively from M4 to M6 to reach, at M9, expression levels below those of wild type mice. Conversely, in the hippocampus of 5XFAD mice, their expression is repressed at M1 and upregulated at M9. Such differential expression patterns may highlight distinct temporally-regulated protective capacities, as observed in cultures of oxygen- and glucosedeprived astrocytes from cortex and hippocampus [39].
IPA was then undertaken to investigate the most affected networks during the time course of disease progression. When considering all DEGs at M4, M6 and M9 (after the onset), processes associated to the dysregulated genes mainly relate to inflammatory and immune responses (Figure 3A). As an example, Figure 3B maps some genes associated to the complement, major histocompatibility complexes (MHCs) and toll-like receptors (TLRs).

Such a presence of immune markers in the hippocampus and cortex of the 5XFAD mice is not surprising since they are produced in neurons, astrocytes and resident microglia. In a healthy brain, they illustrate the "neuro-immune" system that exists in the central nervous system, where, for instance, complement cascade tags neurons destined to destruction [40]. With age and repeated insults, these processes may spiral out of control and lead to degeneration. Through the upregulation of inflammatory/immune markers, the 5XFAD brain recapitulates the dysfunction of the resident immune network seen in $\mathrm{AD}[41,42]$. 

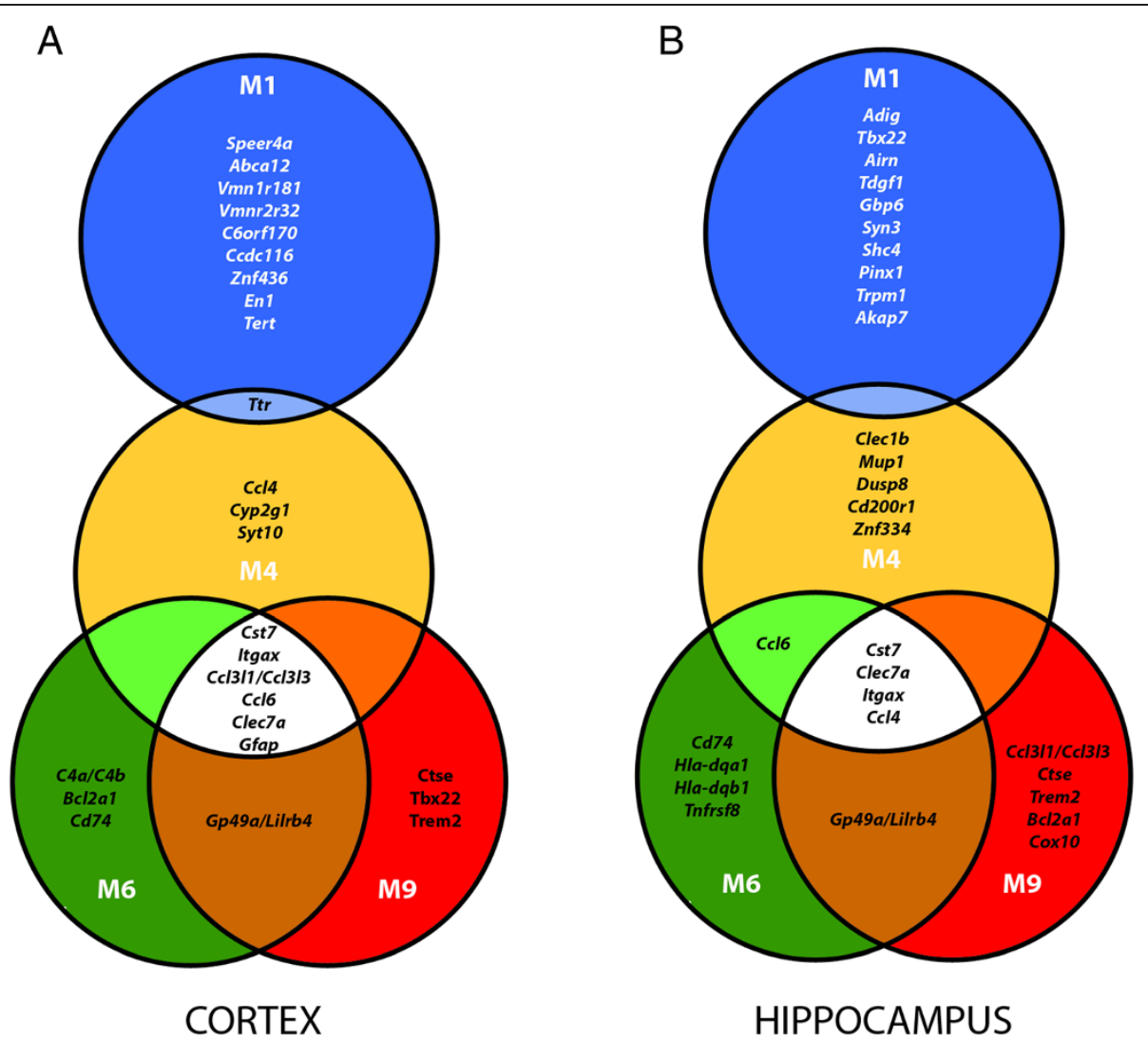

Figure 2 The top ten most up-regulated genes at each age, in cortex and hippocampus, illustrate the alteration of inflammatory and immune processes from $\mathbf{M} 4$ onwards. Venn diagrams representing the top ten up-regulated genes in cortex (A) and hippocampus (B) of 5XFAD mice at M1 (blue), M4 (yellow), M6 (green) and M9 (red). Genes are listed by rank of fold change, the cut-off for analysis being FC > 1.5 when comparing gene probe signals from 5XFAD with wild type mice. Note that only Ttr dysregulation is present at both M1 and M4 in the cortex while the other 9 genes are specific to M1. However, at M4, M6 and M9,60\% and $40 \%$ of these genes are consistently dysregulated in the cortex and the hippocampus, respectively.

Table 1 Upregulated genes with their fold change related to inflammation and immune processes in the cortex and hippocampus of 5XFAD mice at M1, M4, M6 and M9

\begin{tabular}{|c|c|c|c|c|c|c|c|c|c|}
\hline \multirow[b]{2}{*}{ Gene } & \multirow[b]{2}{*}{ Probe } & \multicolumn{4}{|c|}{ Cortex } & \multicolumn{4}{|c|}{ Hippocampus } \\
\hline & & M1 & M4 & M6 & M9 & M1 & M4 & M6 & M9 \\
\hline$\overline{C l e c 7 a}$ & A51P246653 & 0.8 & 12.1 & 35.0 & 30.9 & 1.1 & 15.9 & 32.2 & 32.5 \\
\hline Cst7 & A51P137419 & 1.0 & 74.7 & 63.5 & 140.2 & 1.3 & 100.5 & 118.4 & 145.8 \\
\hline $\operatorname{ltgax}$ & A51P303424 & 0.7 & 16.3 & 13.4 & 19.6 & 0.8 & 16.1 & 14.8 & 23.2 \\
\hline $\mathrm{CCl} 3$ & A51P140710 & 1.0 & 15.8 & 14.7 & 15.4 & 0.6 & 11.3 & 7.3 & 17.3 \\
\hline $\mathrm{Ccl} 6$ & A51P460954 & 1.4 & 12.4 & 9.4 & 13.4 & 1.4 & 13.7 & 10.8 & 9.7 \\
\hline Gfap & A55P2157245 & 1.1 & 3.4 & 6.1 & 4.4 & 1.1 & 2.2 & 3.0 & 5.4 \\
\hline Gfap & A52P52303 & 1.1 & 5.2 & 8.4 & 5.0 & 1.1 & 2.8 & 3.1 & 4.5 \\
\hline Gfap & A55P2157250 & 1.2 & 8.1 & 8.6 & 11.8 & 0.9 & 4.0 & 8.0 & 3.5 \\
\hline $\mathrm{CC} / 4$ & A51P509573 & 0.9 & 9.0 & 7.3 & 9.9 & 0.9 & 12.7 & 10.7 & 11.3 \\
\hline Ttr & A65P19832 & 12.2 & 8.7 & 2.5 & 0.7 & 0.2 & 1.2 & 1.0 & 1.5 \\
\hline KI & A52P439358 & 2.9 & 3.0 & 1.2 & 0.5 & 0.2 & 1.2 & 0.6 & 2.2 \\
\hline
\end{tabular}

Fold changes are indicated in bold when $\mathrm{FC}>1.5$. 


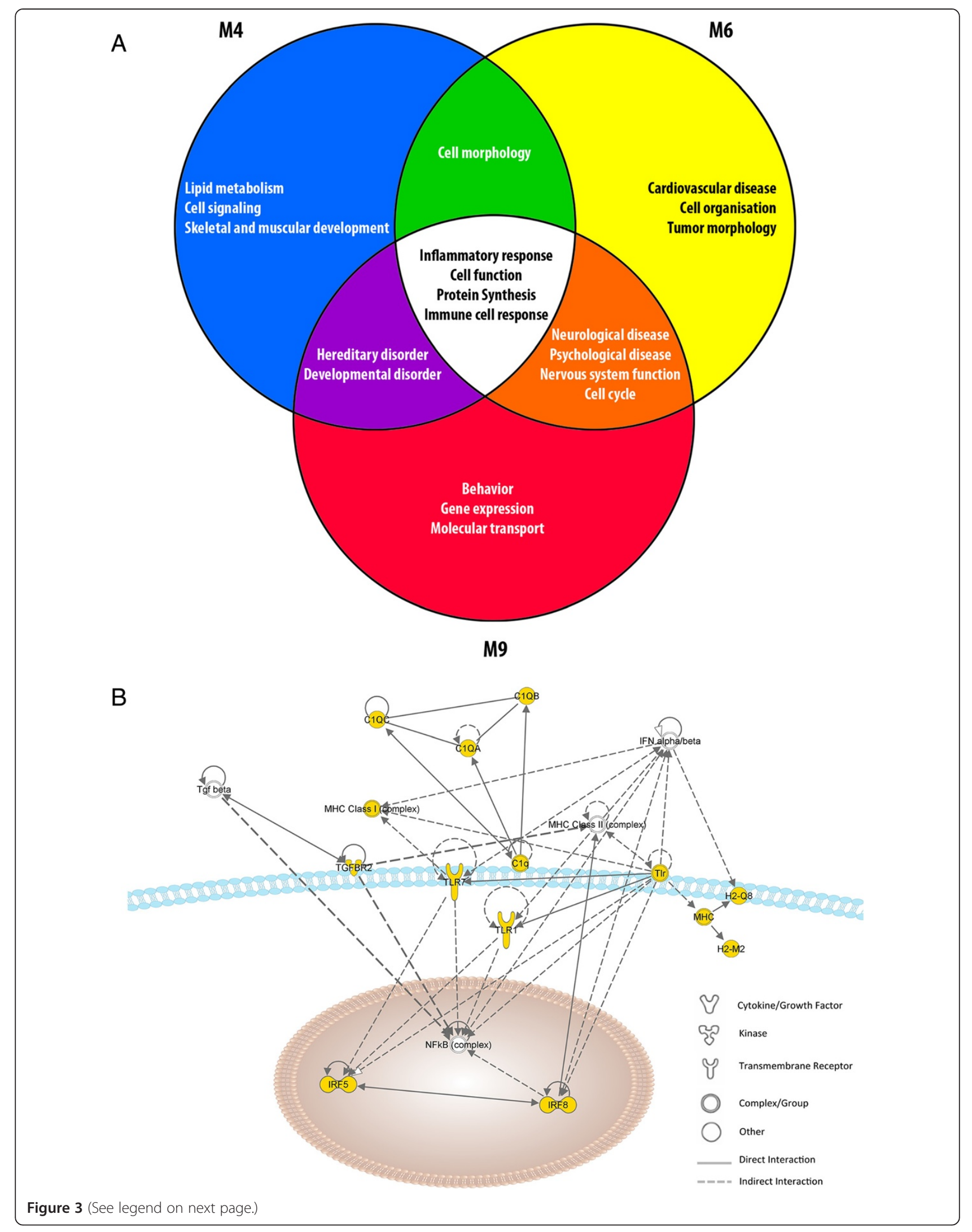


(See figure on previous page.)

Figure 3 Metabolic pathways associated to gene dysregulation in 5XFAD cortex and hippocampus at M4, M6 and M9: common versus age-specific processes. Biological functions and metabolic pathways associated to gene expression dysregulation were identified using Ingenuity Pathway Analysis (IPA). (A) Data from both the cortex and hippocampus were analyzed as one dataset and the main metabolic pathways affected were clustered according to age (M4, blue; M6, yellow; M9, red). The metabolic pathways affected across all three ages are represented in white and are related to inflammatory and immune responses. (B) The main metabolic pathway affected at M4, M6 and M9 relates to infectious disease, cellular function and antigen presentation.

In addition to inflammatory and immune changes, IPA identified functional links between genes affected from M6 onwards and neurological and psychological diseases (Figure 3A). Changes in genes associated with impaired cognitive functions are found to be a significant feature of M9. This is consistent with published studies reporting abnormal behaviors in 5XFAD mice starting at M6 and strongly consolidated by M9 [7,12,13,19,20,43,44].

These observations suggest that disrupting the intricate balance between neurons and surrounding immune cells may lead to neuronal dysfunction and cognitive deterioration $[45,46]$.

\section{Establishment of neuroinflammation through activation of complement}

A dramatic increase in inflammation stands out as the most striking transcriptomic result. Neuroinflammation is a well-known hallmark of AD and is characterized by the activation of astrocytes and microglia, which appears in the 5XFAD mouse model near and concomitantly to amyloid plaques [1]. In various types of brain insults, peripheral leukocytes infiltrate the injured brain [47-49] and intensify the neuroinflammatory response through pro-inflammatory mediators, free radicals, lipid peroxidation and oxidative stress [50-52]. Their infiltration is mediated, in part, by CD11/CD18 integrins expressed in neutrophils and monocytes/macrophages.

In our study, in addition to Cd11c-encoding gene Itgax, genes such as Itgam, Itgb3, and Itgb2, encoding respectively Cd11, Cd61 and Cd18, are all overexpressed in the 5XFAD mice (Table 2). Most of these integrins are transcriptionally induced by IL- $1 \beta$ and/or $A \beta$ through TLR2-mediated signaling [53]. In keeping with this, we found an upregulated expression of Tlr2 at M4, M6 and M9 (Table 2). Increases in transcript levels of inflammatory markers such as $C d 11 b, I l-1 \beta, T n f-\alpha$ and $T l r 2$ have already been observed in 6 months old 5XFAD mice [54].

Moreover, the expression of several members of the complement, known immune effectors, is also upregulated, such as C3, C4, C1qa, C1qc and C1qb, which are all overexpressed in the cortex of AD patients [55]. CD18 interacts with CD11b or CD11c to form the C3 receptor (CR3) and $\mathrm{C} 4$ receptor (CR4), respectively. C3 and $\mathrm{C} 4$ ligands bind to their cognate receptors, C3R and C4R (Figure 4). Activation of these receptors is reportedly part of the complement-induced inflammation in AD mouse models and patients [56-61] and influences microglia to adopt protective or deleterious phenotypes in AD [31,62].

On the whole, our results point to a major raise in inflammation in the 5XFAD brain, linked to complement activation and presumably to immune cell infiltration, reminiscent of similar findings in AD patients and other mouse models [63-68].

\section{Altered expression of interferon gamma-induced genes}

In a second approach, we applied more stringent criteria for gene selection (see Materials and methods) to identify functional networks highly modulated in our model: we focused on genes upregulated in both hippocampus and cortex, from M4 to M9 or at consecutive time points (M4/M6 and M6/M9). We then explored the published data on these dysregulated genes to map out the molecular and cellular players at stake. To this end, we used IPA as well as PredictSearch, another software for the design of functional networks [69-74]. This combined analysis reveals numerous IFN- $\gamma$-induced genes, which belong to a larger set of genes known as interferon stimulated genes or ISGs (Figure 5). However, we did not observe any change in IFN- $\gamma$ gene expression in our study. Although post-transcriptional regulation cannot be excluded, we can postulate that IFN- $\gamma$ transcription occurs either transiently in brain cells or outside

Table 2 Upregulated genes related to complement activation in the cortex and hippocampus of 5XFAD mice at M1, M4, M6 and M9

\begin{tabular}{|c|c|c|c|c|c|c|c|c|c|}
\hline \multirow[b]{2}{*}{ Gene } & \multirow[b]{2}{*}{ Probe } & \multicolumn{4}{|c|}{ Cortex } & \multicolumn{4}{|c|}{ Hippocampus } \\
\hline & & M1 & M4 & M6 & M9 & M1 & M4 & M6 & M9 \\
\hline Itgam & A55P1977929 & 0.9 & 1.5 & 1.2 & 1.9 & 1.1 & 2.0 & 1.8 & 1.6 \\
\hline $\operatorname{ltg} b 2$ & A51P262208 & 1.0 & 2.5 & 2.6 & 3.4 & 1.0 & 2.3 & 2.4 & 2.5 \\
\hline $\operatorname{ltg} 63$ & A52P553890 & 0.9 & 1.3 & 2.0 & 1.5 & 0.9 & 1.8 & 1.9 & 3.0 \\
\hline Tlr2 & A51P452629 & 1.0 & 2.7 & 3.6 & 3.3 & 0.6 & 3.2 & 3.6 & 5.1 \\
\hline C3 & A51P110301 & 1.6 & 1.0 & 3.5 & 1.6 & 0.9 & 1.2 & 5.2 & 6.3 \\
\hline$C 4 b$ & A55P2078633 & 1.1 & 2.6 & 9.0 & 3.7 & 0.8 & 2.6 & 4.0 & 5.6 \\
\hline Clqa & A51P181451 & 1.1 & 2.6 & 3.2 & 4.0 & 1.0 & 3.0 & 3.8 & 4.7 \\
\hline$C 1 q b$ & A51P351860 & 1.0 & 2.3 & 2.9 & 3.2 & 1.0 & 2.6 & 5.1 & 2.9 \\
\hline $\mathrm{Clqc}$ & A51P102789 & 1.0 & 2.8 & 2.0 & 5.7 & 1.2 & 3.0 & 4.6 & 4.2 \\
\hline
\end{tabular}

Fold changes are indicated in bold when FC $>1.5$. 


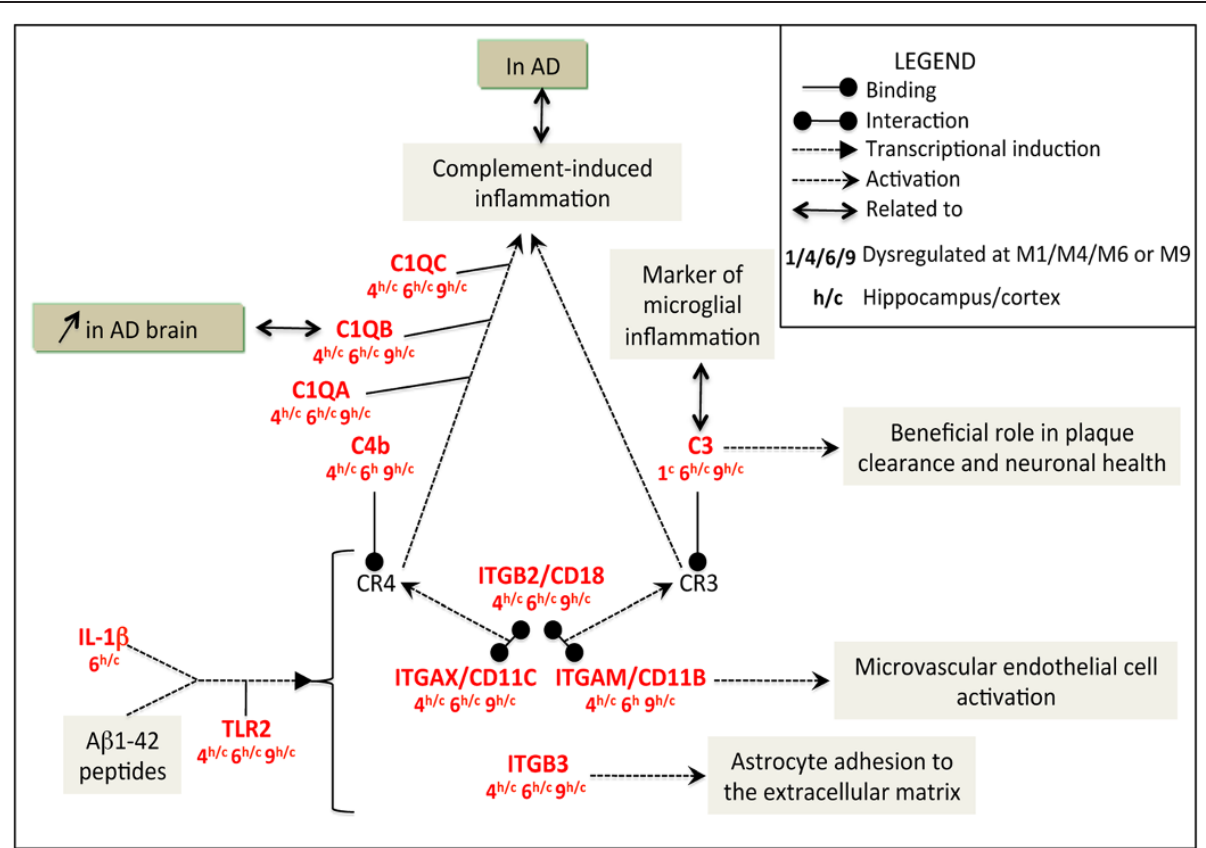

Figure 4 The complement-induced inflammation pathway: an important mediator of neuroinflammatory processes from M4 onwards. This functional network was designed using the text-mining software, PredictSearch, based on more stringent criteria than for the above figure: only upregulated DEGs (with a FC > 1.5) found in both the cortex and hippocampus and at consecutive time points (M4/M6; M6/M9 or M4/M6/M9) were considered for analysis. Top right corner: legend for Figures 4, 5, 6, 7.

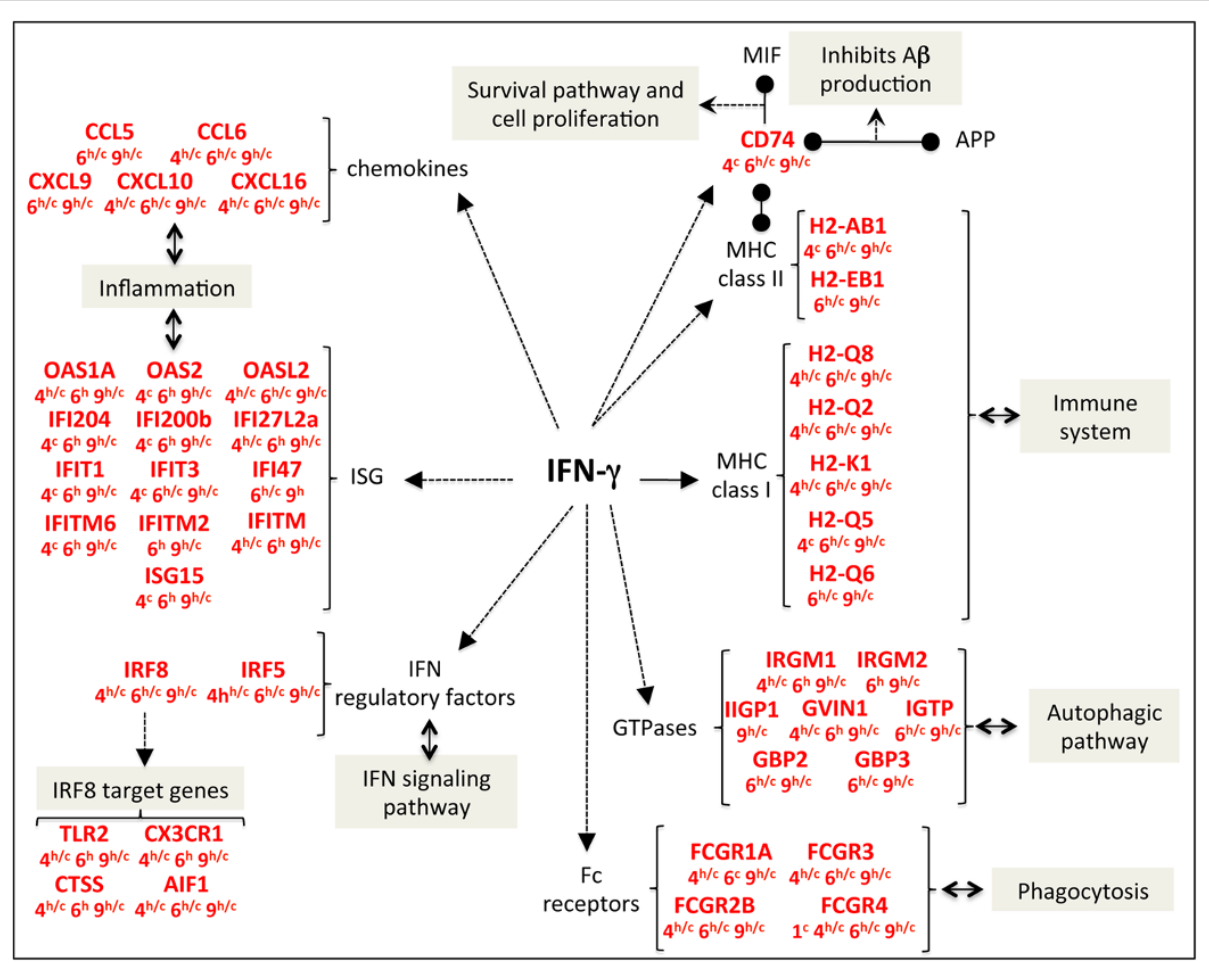

Figure 5 A large proportion of upregulated genes belong to the family of IFN $\gamma$-induced genes: engagement of inflammatory, immune, autophagic and phagocytic pathways. Legend for this figure is located in the top right corner of Figure 4. 
the brain, in peripheral blood cells. IFN- $\gamma$ can be produced in the brain by glial cells [75]. However, several reports argue in favor of $\mathrm{T}$ cell infiltration in $\mathrm{AD}[63,64]$. In post mortem $\mathrm{AD}$ brain, peripheral $\mathrm{T}$ cells cluster around plaques in areas of important gliosis [76-78]. Disruption of the blood-brain barrier has been reported in M8 5XFAD mice [79]. A recent study also demonstrates that a significant infiltration of $\mathrm{T}$ cells occurs in the brain of APP/PS1 transgenic mice and that these cells secrete IFN- $\gamma$ [80]. In the same study, transferring A $\beta$-specific Th1 cells to APP/PS1 mice increased microglial activation and $A \beta$ deposition and worsened cognitive performances in the Morris water maze. These observations warrant more studies to test the hypothesis that, in the 5XFAD brain, infiltrated T cells may potentially release IFN- $\gamma$, activate microglia and stimulate expression of IFN- $\gamma$ induced genes.

As described below, these genes are involved in the regulation of different processes, including immunity, inflammation and GTPase signaling (Figure 5).

Concerning the potential role of the immune system, major histocompatibility complex (MHC) genes are expressed in microglia upon cytokine stimulation in the inflamed brain [81] and both MHC class I and II are known to be upregulated in sporadic forms of human $\mathrm{AD}$ [82]. A role for MHC class II genes in the 5XFAD mice is supported by the parallel increase in the expression of Cd74 (Figure 5), which acts both as chaperone for MHC class II molecules and as receptor for MIF (macrophage migration inhibitory factor). CD74 is also increased in $\mathrm{AD}$ cases compared with age-matched controls, notably in neurofibrillary tangles-bearing neurons, amyloid plaques and microglia [83]. Thus, expression of MHC class II genes highlight the predominance of microglia activation in the 5XFAD mice. In response to IFN- $\gamma$, a rise in microglial MHC class II genes may enhance antigen presentation to $\mathrm{T}$ cells, which, in turn, might contribute to immune-mediated damages to neurons. Interestingly, at least at a certain stage of the disease, $C d 74$ expression may also denote a protective effect. Indeed, interaction of CD74 with MIF promotes a cell survival pathway and its interaction with APP blocks $\mathrm{A} \beta$ production $[84,85]$.

In our analysis, a second large cluster of genes induced by IFN- $\gamma$ and dysregulated in 5 XFAD brain encodes proteins with GTPase activity (Figure 5), such as $\operatorname{Irgm} 1$ and Irgm2 (members of the Immunity-Related GTPase family $M$ [86]), Igtp/Irgm3 (IFN- $\gamma$ induced GTPase), and Iigp1/Irga6 (interferon induced GTPase 1). Moreover, the expression of another GTPase gene, Gvin1 (very large interferon inducible 1) and two members of the guanylate-binding protein genes, $G b p 2$ and $G b p 3$, is also higher in 5XFAD animals. GBPs belong to another family of GTPases and are the most abundant proteins that accumulate in fibroblasts or macrophages in response to IFN- $\gamma$ stimulation [87]. A number of other GTPases, not described to be regulated by IFN- $\gamma$, but related to TGF- $\beta$ activity, are also overexpressed in our model.

GTPases such as Irgm1 regulate, during ischemic stroke, survival and neuronal autophagy [88], a process that eliminates dysfunctional cell components using lysosomes. Irgm 1 exacerbates experimental auto-immune encephalomyelitis by promoting disruption of the bloodbrain and blood-cerebrospinal fluid barriers [89]. In addition to controling cell death or survival [90-92], murine IRGs affect protein aggregate formation and clearance $[93,94]$ and altogether, these functions engage the autophagic pathway [91].

A possible involvement of autophagy in 5XFAD animals is also supported by the increased expression of known targets of Tfeb, a transcriptional factor involved in lysosomal biogenesis $[95,96]$. These Tfeb targets include Gusb (betaglucuronidase), Naglu, Hexa, Hexb, and Ctsd [95,97], which are greatly expressed in the 5XFAD mice from M4 to M9 in both cortex and hippocampus (Table 3). Interestingly, the expression of Gusb was upregulated in $\mathrm{A} \beta$-resistant cells and might illustrate a protective effect against $A \beta$ toxicity [98]. Moreover, a role for presenilins in regulating lysosomal function has been demonstrated [97] and several lines of evidence suggest that endosomes/lysosomes are involved in $A \beta$ production $[99,100]$. Thus, our results highlight the possible activation of the endosomal/lysosomal system in the 5XFAD brain, in keeping with observations in this model [101] and in human AD brains [102].

\section{Potential role of IRF8 in the expression of interferon gamma-regulated genes}

We next explored in more detail which pathways were activated immediately downstream of IFN- $\gamma$ in the 5XFAD brain. As detailed below, we discovered an unexpected downstream effector of IFN- $\gamma$ : Interferon Regulatory Factor 8 (IRF8). Induction of MHC class I genes by IFN- $\gamma$ generally depends on the JAK/STAT pathway that targets the ISRE (Interferon Stimulating Response Element) motif [103]. By contrast, the expression of MHC class II genes requires that the transcriptional factor CIITA forms a complex with DNA-binding factors targeting the MHC class II promoter [104]. The increased expression of both MHC class I and II genes observed in 5XFAD mice suggests that the two IFN- $\gamma$-signaling pathways are altered. However, among the factors known to participate in these pathways, only Stat 3 and Socs 3 display a significant upregulated expression in both tissues of 5XFAD mice, and not before M9. Therefore, it can be assumed that novel pathways explain the major rise in IFN- $\gamma$-induced genes.

Among interferon-stimulated genes, it is noteworthy that genes encoding transcription factors Irf5 and Irf8 are highly upregulated in the 5XFAD mice, from M4 to 
Table 3 Upregulated genes, fold changes, and associated functional categories for genes consistently dysregulated from M4 to M9

\begin{tabular}{|c|c|c|c|c|c|c|c|c|c|c|}
\hline \multirow[b]{2}{*}{ Gene } & \multirow[b]{2}{*}{ Probe } & \multicolumn{4}{|c|}{ Cortex } & \multicolumn{4}{|c|}{ Hippocampus } & \\
\hline & & $\mathrm{M} 1$ & M4 & M6 & M9 & M1 & M4 & M6 & M9 & \\
\hline Gusb & A51P211491 & 0.9 & 2.5 & 3.2 & 3.2 & 1.1 & 3.0 & 3.6 & 3.9 & \multirow{5}{*}{ Lysosomal biogenesis } \\
\hline Naglu & A52P504361 & 1.0 & 2.1 & 2.1 & 2.2 & 0.8 & 1.7 & 2.2 & 2.0 & \\
\hline Hexa & A51P282667 & 1.1 & 1.9 & 2.0 & 2.3 & 1.2 & 1.7 & 2.3 & 2.4 & \\
\hline Hexb & A51P453111 & 1.0 & 2.5 & 2.0 & 3.2 & 0.9 & 2.8 & 2.0 & 3.3 & \\
\hline Ctsd & A65P13209 & 1.1 & 3.0 & 4.4 & 2.4 & 0.9 & 2.8 & 3.8 & 3.1 & \\
\hline Tgfb1 & A51P390715 & 1.1 & 1.8 & 1.7 & 2.3 & 0.8 & 2.3 & 2.6 & 1.6 & \multirow{3}{*}{ TGF- $\beta$ signaling } \\
\hline Tgfbrl & A51P2137206 & 1.1 & 1.5 & 1.7 & 1.7 & 0.8 & 1.6 & 1.4 & 1.9 & \\
\hline Tgfbr2 & A51P450573 & 1.0 & 1.9 & 2.1 & 2.3 & 1.0 & 2.2 & 2.0 & 3.7 & \\
\hline Aif1 & A51P400543 & 1.0 & 2.1 & 2.4 & 2.2 & 1.0 & 2.5 & 2.3 & 2.9 & \multirow{4}{*}{ Markers of microglial activation } \\
\hline Ptprc & A55P1990324 & 1.0 & 2.0 & 1.7 & 2.0 & 1.0 & 2.0 & 2.1 & 2.5 & \\
\hline Cd86 & A55P1971951 & 0.9 & 1.8 & 2.3 & 2.5 & 1.1 & 2.5 & 3.0 & 3.5 & \\
\hline Cd14 & A51P172853 & 1.0 & 2.7 & 3.2 & 3.8 & 1.0 & 2.6 & 3.6 & 3.3 & \\
\hline lgfi & A55P2031631 & 0.9 & 2.6 & 2.0 & 5.1 & 1.0 & 3.0 & 3.0 & 4.2 & \multirow{3}{*}{ Protective activities } \\
\hline Osmr & A51P319460 & 0.9 & 1.6 & 2.7 & 3.1 & 0.7 & 2.5 & 3.0 & 5.3 & \\
\hline Grn & A51P192800 & 0.9 & 2.5 & 2.3 & 2.6 & 1.1 & 2.2 & 3.0 & 2.5 & \\
\hline
\end{tabular}

Fold changes are indicated in bold when FC $>1.5$.

M9 (Figure 5). Irf8 stands out as a particularly interesting effector of IFN- $\gamma$. Expressed predominantly in hematopoietic cells and further increased upon treatment with IFN- $\gamma$ [105-107], Irf8 is required to propagate pro-inflammatory signals and to activate microglia [108]. IRF8 also instructs myeloid progenitors to become mononuclear phagocytes [109,110]. A combination of genome-wide methods already confirmed the crucial role of IRF8 in regulating early immune response, including phagosome maturation, antigen processing and presentation $[111,112]$. Interestingly, 5XFAD mice overexpress most of the Irf8 target genes supporting these processes (Figure 5). This strongly suggests that Irf8 accounts for the IFN- $\gamma$ regulated processes described here and therefore represents a key player in the 5XFAD pathology.

Alternatively, IRF8 expression can also be induced through TGF- $\beta$ [113], which is highly overexpressed in 5XFAD mice, along with transcripts for its receptors, Tgfbr1 and Tgfbr2 (Table 3). This pathway inhibits macrophages and suppresses microglial expression of $\mathrm{MHC}$ antigens [114,115], and its activation in 5XFAD brain might therefore be a protective response against sustained microglial activation.

\section{Involvement of NADPH oxidase (NOX) complex in microglial activation}

The NOX complex contributes to persistent microglial activation and reactive oxygen species production, which leads to an increase in oxidative stress, regarded as an early sign of AD pathophysiology [116,117]. Moreover, studies on different AD mouse models, including 5XFAD mice, reported increased levels of oxidative damage, which appear before $\mathrm{A} \beta$ deposition and therefore constitute an early event in disease pathogenesis $[24,44,118,119]$. Actually, a recent proteomic analysis revealed that the most affected biological processes in M4 5XFAD hippocampus include cell redox homeostasis and response to oxidative stress [120].

In our study, most of the genes encoding NOX components as well as NOX associated factors, Fc receptors, Vav and Rac2, are overexpressed as early as M4 in 5XFAD mice (Figure 6). Of note, genes encoding the NOX subunits as well as Fcgr1a/CD64 (Fc fragment of IgG receptor, high affinity 1a) are regulated by IFN- $\gamma[107,121-123]$. Their co-expression is in line with the observation that clustering of $\mathrm{FC} \gamma$ receptors activates VAV proteins (Rho/Rac guanine nucleotide exchange factors), leading to robust superoxide generation through NOX [124-126].

Several studies provide strong evidence for the involvement of NOX and its downstream oxidative signaling pathway in the toxic effects elicited by $A \beta$. In $A D$ brains, $\mathrm{A} \beta$ is thought to act on NOX in microglial cells, which produce neurotoxic superoxide [127]. A $\beta$ also induces oxidative stress in hippocampal astrocytes through a mechanism sensitive to NOX inhibitors [128].

According to these observations, NOX activation can occur in either microglia or astrocytes. However, it is likely that, in our model, NOX is predominantly activated in microglia. Indeed, in addition to MHC class II 


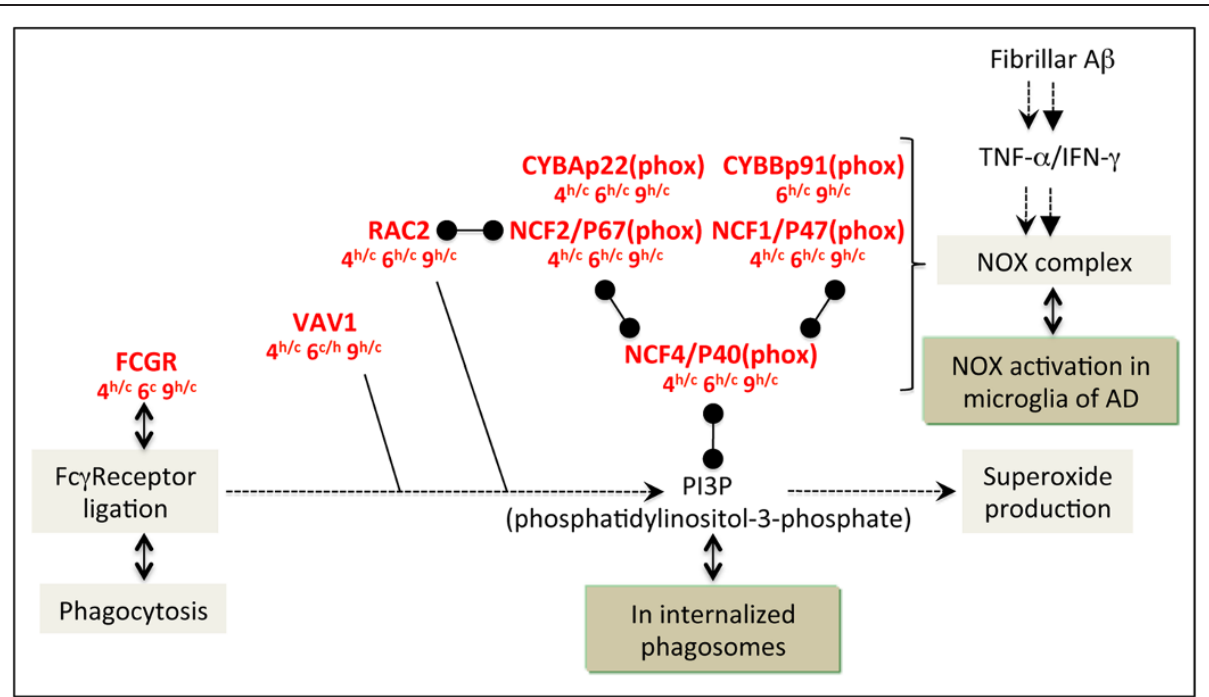

Figure 6 Increased expression of genes involved in the NADPH oxidase complex. Legend for this figure is located in the top right corner of Figure 4.

genes and $C d 74$, markers of microglial inflammation are strongly overexpressed in 5XFAD mice (Table 3), notably Aif1/Iba1, Ptprc/Cd45, Cd68, Cd86 and Cd14 [83,129-131]. In line with the microglial origin of NOX activation, expression of the $\mathrm{Fc} \gamma$ receptor-encoding genes is found around senile plaques and in ramified microglia, throughout the cortex and the white matter of normal and AD brains [132]. Furthermore, RAC2, which controls NOX activation by preferentially interacting with the NCF2/p67(phox) NOX subunit [133], is largely predominant in human phagocytes [134].

\section{Microglial phagocytosis}

Microglia/brain macrophages constitute about $12 \%$ of the cells in the central nervous system, and, in addition to antigen presentation, exhibit phagocytosis. Microglia can phagocytose $A \beta$ fibrils in vitro and in vivo [135]. Nevertheless, $A \beta$ phagocytosis is inefficient in $\mathrm{AD}$ brain despite the presence of abundant activated microglia [136]. One possible explanation may be that exposure of microglia to fibrillar $\mathrm{A} \beta$ in vitro can induce mechanisms distinct from those used by classical phagocytic receptors, FCGR1 and FCGR3, or complement receptors (Figure 7). This novel

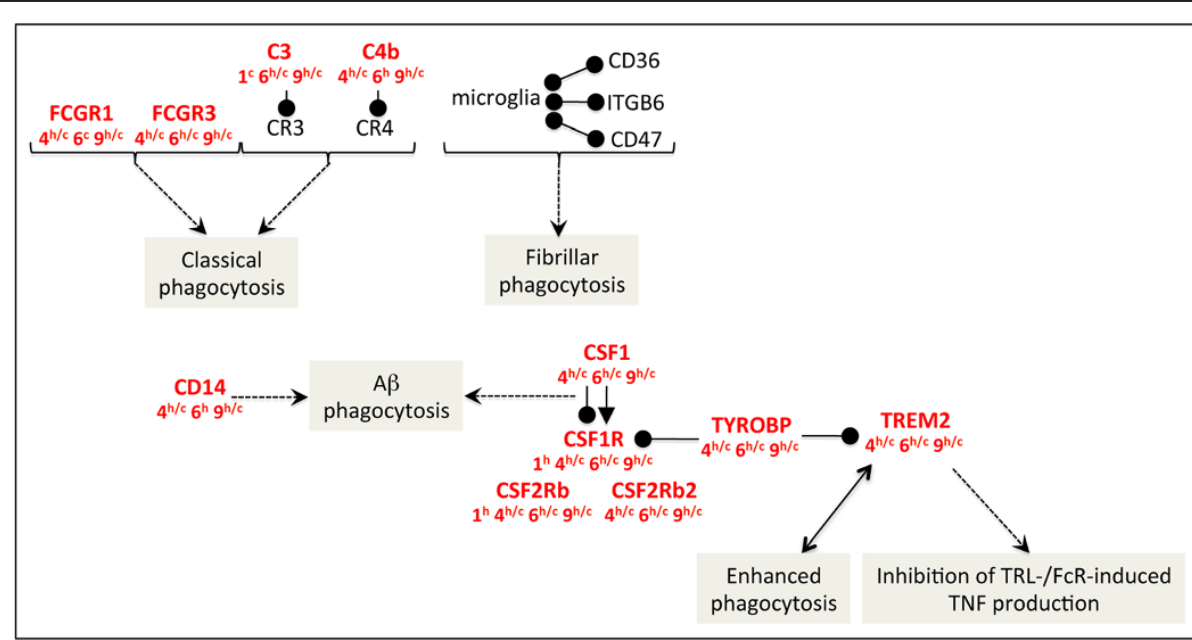

Figure 7 Increased microglial activation and induction of associated neuroprotective signaling pathways. Legend for this figure is located in the top right corner of Figure 4. 
phagocytosis would require the interaction of microglia with CD36, ITGB6, and CD47 [137].

Phagocytosis of $A \beta$ by microglia can be also mediated by CD14 [138], which is detected in brains of AD patients, or by CSF1 (macrophage colony stimulating factor 1) and its receptor, CSF1R (Figure 7). Interestingly, Csf1r signaling in injured neurons facilitates protection and survival [139]. The Csf1/Csf1r complex co-signals through Tyrobp, which, together with its receptor, Trem2, activates signal transduction leading to brain myelination and inflammation [140]. The signaling involving Csf1/Csf1r/ Trem $2 /$ Tyrobp likely plays a role in the 5XFAD physiopathology since all the corresponding genes are strongly upregulated from M4 to M9 in cortex and hippocampus (Figure 7). Moreover, recent reports show that rare TREM2 variants predispose to AD [141,142] and Trem2 mRNA and protein are increased in a transgenic mouse model of $\mathrm{AD}$ [141]. It has been proposed that these changes represent a response to rising levels of $A \beta$ [141]. Localized to microglia around plaques and neurons in $\mathrm{AD}$ models, Trem 2 controls two signaling pathways that regulate the reactive phenotype in microglia (Figure 7). The first of these pathways couples increases in Trem 2 expression on microglia with enhanced phagocytosis [143-145]. This could lead to the removal of cell debris and the clearance of $\mathrm{A} \beta$ in $\mathrm{AD}$ and promote the alternative "protective" activation state of microglia. The second Trem 2 signaling pathway suppresses inflammatory reactivity and represses cytokine production and secretion [144], notably TLRand FcR-induced TNF production $[146,147]$. Thus, in addition to its protective role by activating phagocytosis of apoptotic neurons and $A \beta$, the predominant role of the TYROBP/TREM2 complex might be to inhibit, rather than to activate, the innate immune system.

Altogether, these transcriptional changes indicate that, in 5XFAD mice, microglial activation and the resulting phagocytosis are predominant processes, which are already initiated at M4 and maintained at least until M9.

\section{Other neuroprotective activities}

The 5XFAD transcriptomic data identified numerous genes involved in neuroprotective pathways. In addition to those already discussed, we found an upregulation of genes encoding Igf1 (insulin growth factor 1), Osmr (oncostatin $M$ receptor) and Grn/Pgrn (granulin) (Table 3).

Insulin and IGF1 signaling is disturbed in AD brain and in 5XFAD hippocampus $[120,148,149]$. Igf1 can either protect or increase LPS-induced damage in the developing rat brain [150]. A possible explanation for these apparently contradictory observations may be that modulation of the cellular response to oxidative stress by Igf1 is celldependent [151]. Contrary to what has been observed in neurons [152], astrocyte-specific overexpression of IGF-1 protects hippocampal neurons [153].
Neuroprotection can also be elicited through OSM (oncostatin $\mathrm{M}$ ), a cytokine with anti-inflammatory activities. In response to IL- $1 \beta$ or TNF- $\alpha$, astrocytes produce prostaglandin E2, which then induces Osm expression in microglia [154]. Upon binding to a complex formed between its receptor, OSMR, and gp130 [155], OSM can in turn attenuate expression of IL- $1 \beta$ or TNF- $\alpha$ [156]. Therefore communications between microglia and astrocytes may account for the balance of protective and destructive actions by these cells. Although Osm expression levels were similar in 5XFAD and wild type mice, elevated expression of Osmr might increase the constitutive Osm activity detected in neurons, astrocytes and microglia [154]. Besides, the protective effect of Osm on neuronal cell death is mediated by the Jak/Stat3 signaling pathway [157]. In the 5XFAD brain, this neuroprotective effect may be attenuated through the OSM-induced upregulation of Socs3, a known inhibitor of Jak/Stat signaling [157].

Finally, GRN/PGRN, an AD marker [158], is involved in the modulation of the neuroinflammatory response. Supporting this role, microglia display increased Grn/Pgrn expression following a variety of acute and chronic insults to the central nervous system [159]. Grn/Pgrn can increase endocytosis of extracellular peptides such as $A \beta$ and affects microglial proliferation, recruitment, differentiation, activation and phagocytosis [159]. Grn/Pgrn is a potent inhibitor of TNF- $\alpha$ and promotes the upregulation of antiinflammatory cytokines such as Il-4, Il-10 and Il-5 [159]. Direct interaction of GRN/PGRN with the TNF receptor also blocks the pro-inflammatory actions of TNF- $\alpha$ [160]. However, GRN/PGRN can be cleaved by extracellular proteinases such as MMP-9, -12 and -14 to produce granulin/GRN peptides, which increase the expression of IL-1 $\beta$, IL- 8 and TNF- $\alpha[161,162]$. Therefore, a balance between PGRN and its processed form GRN may determine the contributions of certain cell types or subtypes to neuroprotection or neuroinflammation and their impact on the 5XFAD pathophysiology.

\section{Limitations of the study}

The aim of this study was to provide an overview of the main networks affected in 5XFAD brain, as revealed by intensive data mining on dysregulated genes observed in transcriptomic profiles. Such a global approach determines tendencies based on the design of networks rather than confirms individual gene modulation at the transcript or protein levels. Given the stringent criteria chosen to filter our data, most of the genes within the described networks are significantly modulated in both hippocampus and cortex from M4 to M9. Investigating the role of non-shared DEGs at given time points and analyzing specificities of each brain region is beyond the scope of this study, but deserves further investigation in order to elucidate the precise molecular mechanisms at 
play. Importantly, many DEGs and several signaling pathways, associated to AD, have been found to be misexpressed in the 5XFAD model by two independent studies [30,31].

Further understanding of the signaling pathways affected in this mouse model, with the aim to link it to human $\mathrm{AD}$, would entail broadening the study to additional brain regions. The entorhinal cortex, for instance, is known to be the site of early neuron loss in human $\mathrm{AD}$ and has recently been shown to be affected by amyloid deposition, as early as 2 months of age in both female and male 5XFAD mice [163].It would therefore be of great interest to investigate the transcriptomic profile of this brain region in future studies.

The study would also benefit from a comparison of transcriptomic profiles between female and male mice. Female 5XFAD animals are more affected at the histological and behavioural levels than male mice $[9,163]$, possibly as a consequence of decreased estrogen levels. Variations in estrogen levels can directly impact on transcriptomic profiles through modulation of the genome and signaling pathways. In the current study, IPA analysis revealed a large proportion of DEGs potentially regulated by estrogens and one of their receptors, ESR1 (data not shown). We also observed a dysregulated expression of genes directly linked to the effects of testosterone, reinforcing the idea that differential gene modulation during the time course of the disease could occur between male and female mice. Future studies should take hormonal impact into consideration.

Finally, based on the data presented here and in previous studies, there is no doubt that a fine understanding of pathogenesis necessitates deciphering early molecular events. As a result, it would be of great importance to enlarge the current study to a finely tuned time window that spans for M1 to M4, when histological markers start developing.
Despite such considerations, the data presented here offers, for the first time, the possibility to understand time-dependent variations in the inflammatory and immune pathways of the 5XFAD model. Altogether, these data confirm that this transgenic model, along with the generated dataset, is a valuable public resource for screening potential therapeutic molecules targeting dysregulated functions in $\mathrm{AD}$.

\section{Materials and methods}

\section{Animals}

We used 5XFAD transgenic mice, which overexpress two transgenes bearing five mutations linked to familial AD: human APP (Swedish mutation K670N, M671L; Florida mutation I716V; London mutation V717I) and human presenilin 1 (PSEN1 M146L, L286V), under transcriptional control of the mouse Thy1 promoter. 5XFAD lines from the B6SJL genetic background were maintained by crossing hemizygous transgenic mice with B6SJL F1 breeders. These mice exhibit AD-related symptoms earlier than other animal models and amyloid deposition starts in the cortex and subiculum at 2 months of age [1]. Heterozygous female 5XFAD transgenic animals and wild type controls were obtained after breeding of progenitors purchased from the Jackson Laboratory. Genotyping was performed by PCR analysis of tail DNA in order to detect the human APP gene. Animal experiments were approved by the Ethics Committee of the Medical Faculty of Marseille and were carried out in accordance with the guidelines published in the European Communities Council Directive of November 24, 1986 (86/609/EEC). All efforts were made to reduce animal suffering and the number of mice.

\section{RNA isolation}

Brain tissues were collected from wild type and transgenic 5XFAD mice ( $\mathrm{n}=3$ per group). At different

Table 4 RT qPCR results for two genes known to be upregulated in 5XFAD mice: comparison with the microarray results

\begin{tabular}{|c|c|c|c|c|c|c|c|c|c|c|c|}
\hline \multirow[b]{2}{*}{ Age } & \multirow[b]{2}{*}{ Gene } & \multicolumn{7}{|c|}{ qPCR } & \multicolumn{3}{|c|}{ Microarray } \\
\hline & & Wt 1 & Wt 2 & Wt 3 & $\operatorname{Tg} 1$ & $\operatorname{Tg} 2$ & $\operatorname{Tg} 3$ & Fold change $\mathrm{Tg} / \mathrm{Wt}$ & Wt & $\mathrm{Tg}$ & Fold change $\mathrm{Tg} / \mathrm{Wt}$ \\
\hline \multirow[t]{2}{*}{$\mathrm{M} 1$} & Aif1 & 1.3 & 0.9 & 0.8 & 1.3 & 1.3 & 0.9 & 1.2 & 2098.9 & 2010.3 & 1.0 \\
\hline & Gfap & 1.5 & 0.9 & 0.7 & 1.3 & 1.4 & 0.8 & 1.2 & 6320.3 & 6827.6 & 1.1 \\
\hline \multirow[t]{2}{*}{ M4 } & Aif1 & 1.1 & 1.1 & 0.9 & 2.8 & 1.7 & 1.3 & 3.1 & 2171.1 & 5335.4 & 2.5 \\
\hline & Gfap & 0.9 & 1.3 & 0.9 & 5.5 & 6.1 & 5.1 & 5.5 & 5381.9 & 15329.9 & 2.9 \\
\hline \multirow[t]{2}{*}{ M6 } & Aif1 & 0.9 & 1.0 & 1.2 & 2.8 & 1.7 & 1.3 & 1.9 & 2427.4 & 5530.1 & 2.3 \\
\hline & Gfap & 1.1 & 1.0 & 0.9 & 3.9 & 5.6 & 4.2 & 4.5 & 5694.4 & 17759.7 & 3.1 \\
\hline \multirow[t]{2}{*}{ M9 } & Aif1 & 1.4 & 0.9 & 0.8 & 2.6 & 2.0 & 2.3 & 2.3 & 2551.1 & 7422.3 & 2.9 \\
\hline & Gfap & 1.5 & 0.8 & 0.9 & 5.0 & 7.0 & 5.9 & 5.9 & 5172.5 & 23062.3 & 4.5 \\
\hline
\end{tabular}

Before performing the microarray experiment, RNA from each wild type $(\mathrm{Wt})$ and each transgenic $(\mathrm{Tg})(\mathrm{n}=3$ for each group) animal was tested independently by RT-qPCR for two genes known to be upregulated in 5XFAD mice: Aif1 and Gfap. This table compares results obtained by qPCR from each mouse with results obtained from the pooled RNA for all three animals in the microarray study. The qPCR and microarray gave similar fold changes, shown here in bold. 
designated time points (beginning of M1, M4, M6 and M9), mice were anesthetized with isoflurane and sacrificed to extract brain tissue. Hippocampus and neocortex samples were dissected, snap-frozen in liquid nitrogen and stored at $-80^{\circ} \mathrm{C}$ until use. Total RNA was then isolated from frozen hippocampi and cortices using RNeasy Mini kit (Qiagen, Courtaboeuf, France), according to the manufacturer's instructions. RNA concentration was determined using a Nanodrop 2000 spectrophotometer (Thermo Scientific, ThermoFisher Scientific, Villebon sur Yvette, France) and RNA integrity assessed on an Agilent 2100 Bioanalyzer (Agilent Technologies, Les Ulis, France).

\section{Real-time quantitative PCR (qPCR)}

Before performing microarray experiments, RNA samples extracted from the hippocampus of all animals $(n=3)$ in each group were tested with qPCR in order to quantify the expression of known markers of inflammation in 5XFAD mice. Total RNA $(1 \mu \mathrm{g})$ was subjected to reverse transcription reaction to synthetize cDNA using oligo dT, RNase Out and M-MLV RT enzyme (Invitrogen, ThermoFisher Scientific, Villebon sur Yvette, France) according to the manufacturer's instructions. Two genes, Gfap and Aif1, related to astrocytic and microglial activation respectively, and one housekeeping gene, Gapdh, were selected for pre-validation of samples.

Real-time qPCR experiments were carried out with the 7500 Fast Real-Time PCR system (Applied Biosystems, ThermoFisher Scientific, Villebon sur Yvette, France), using TaqMan ${ }^{\circ}$ Fast Universal PCR Master Mix (2X) and the three $\mathrm{TaqMan}^{\circ}$ Gene Expression Assays (Gfap, Mm01253033_m1; Aif1, Mm00479862_g1 and Gapdh, Mm99999915_g1). Experiments used 7.5 ng of previously prepared cDNA and samples were run in triplicates. Relative expression levels were determined according to the $\Delta \Delta \mathrm{Ct}$ method where the expression level of the mRNA of interest is given by $2^{-\Delta \Delta C T}$ where $\Delta \Delta C \mathrm{CT}=\Delta \mathrm{CT}$ target mRNA - $\Delta$ CT reference mRNA (Gapdh) in the same sample. Results are reported in Table 4 and compared to microarray data for these two genes of interest.

\section{Microarray assay}

Following qPCR pre-validation of individual animals for each time point and condition, RNA samples were pooled $(\mathrm{n}=3)$ for microarray hybridization. Sample amplification, labeling, and hybridization were performed in line with the Agilent one-color microarraybase analysis (low input quick amp labeling) protocol (Agilent Technologies). Briefly, total RNA was reversetranscribed into cDNA using the T7 promoter primer. The reaction intending to synthesize cyanine-3-labeled cRNA from cDNA was performed in a solution containing dNTP mix, T7 RNA polymerase and cyanine
3-dCTP and then incubated at $40^{\circ} \mathrm{C}$ for 2 hours. Labeled cRNA was purified and fragmented before hybridization on Agilent $8 \times 60 \mathrm{k}$ Mouse Gene Expression Arrays (Agilent Technologies, ref: G4852A), containing 62975 oligonucleotide probes, at $65^{\circ} \mathrm{C}$ for 17 hours. Raw microarray signals were scanned and extracted using Agilent Feature Extraction Software (Agilent Technologies). AgiND $\mathrm{R}$ package was used for quality control and normalization. Quantile methods and a background correction were applied for data normalization. Microarray data are available in the ArrayExpress database [164] under accession number E-MTAB-1937.

\section{Microarray data analysis}

Biological interpretation of the data was performed using two different programs. First, Ingenuity Pathway Analysis (IPA, Ingenuity Systems [165]) was used to identify biological functions from the lists of DEGs associated to transgenic animals. The main criteria to validate a differentially expressed gene was a fold change over 1.5 or under -1.5 when considering expression values in the transgenic group relative to the wild type control group. Upregulated and downregulated genes were analyzed in the same datasets to obtain the biologically relevant function categories. Right-tailed Fisher's exact test was used to calculate a p-value determining the top statistically significant biological functions assigned to the data set.

Secondary analysis of the main metabolic pathways and their potential dysfunctions was performed using the Java/ Perl software Predictsearch ${ }^{\circ}$ (Laboratoire Genex [166]), which has been previously described [69,74]. This software characterizes the pathways and functional networks in which the selected genes found to be up- or downregulated are involved. For this mechanistic analysis, only genes not differentially expressed across all time points in wild type animals (ratio between 0.85 and 1.2) but upregulated in transgenic animals (ratio over 1.5) were considered. Predictsearch was then used to generate functional networks based on the total number of differentially expressed genes in both cortex and hippocampus.

\section{Additional files}

Additional file 1: Table S1. Lists of genes and associated fold changes commonly dysregulated at M1, M4, M6 and M9 in (A) cortex and (B) hippocampus.

Additional file 2: Table S2. Common DEGs in cortex and hippocampus at M4, M6 and M9.

\section{Abbreviations}

5XFAD: A strain of transgenic mice that carry mutant human APP and human PSEN1 genes harbouring a total of five mutations linked to familial AD; AD: Alzheimer's disease; APP: Amyloid precursor protein; AB: Beta-amyloid peptide; Aß42: Beta-amyloid peptide 1-42; DEG: Differentially expressed gene; FAD: Familial Alzheimer's disease; FC: Fold change; GTPases: A large family of hydrolase enzymes that can bind and hydrolyze guanosine triphosphate 
(GTP); IFN-y: Interferon gamma; IPA: Ingenuity pathway analysis; ISG: Interferon stimulated gene; M1: One month; M4: Four months; M6: Six months; M9: Nine months; MHC: Major histocompatibility complex; NADPH: Reduced form of NADP+, i.e. nicotinamide adenine dinucleotide phosphate; NOX: NADPH oxidase complex; PSEN1: Presenilin-1; Thy1: Thymocyte antigen 1.

\section{Competing interests}

The authors declare that they have no competing interest.

\section{Authors' contributions}

$\mathrm{VL}$ isolated the RNA, helped perform the microarray assay, analyzed the results and wrote the manuscript. KB bred and genotyped the mice, and carried out the $\mathrm{APCR}$ analysis. BL performed the microarray assay. IV and SR participated in interpreting the data and writing the manuscript. PB analyzed the microarray data and wrote the manuscript. FF designed and coordinated the study, and helped to draft the manuscript. All authors read and approved the final manuscript.

\section{Acknowledgements}

This work was supported by CNRS, Aix Marseille University and grants from the French National Agency for Research (ANR) funding to FF, SR and MK (ADHOC, TIMPAD, PREVENTAD) within the frame of the French Alzheimer's Plan. The work was also supported by grants from Fondation de I'Avenir to FF, and by "Fonds Européen de Développement Régional" FEDER in PACA. $V L$ was recipient of a doctoral fellowship from the French Ministry of Research. KB was granted a research associate fellowship by the French Alzheimer's Plan

\section{Author details}

${ }^{1}$ Aix Marseille Université, CNRS, NICN UMR 7259, 13916 Marseille, France. ${ }^{2}$ APHM, Hôpitaux de la Timone, Service de Neurologie et Neuropsychologie, 13385 Marseille, France. ${ }^{3}$ Aix Marseille Université, TAGC UMR 1090, 13288 Marseille, France. ${ }^{4}$ INSERM, TAGC UMR 1090, 13288 Marseille, France.

Received: 23 June 2014 Accepted: 27 August 2014

Published: 11 September 2014

\section{References}

1. Oakley H, Cole SL, Logan S, Maus E, Shao P, Craft J, Guillozet-Bongaarts A, Ohno M, Disterhoft J, Van Eldik L, Berry R, Vassar R: Intraneuronal betaamyloid aggregates, neurodegeneration, and neuron loss in transgenic mice with five familial Alzheimer's disease mutations: potential factors in amyloid plaque formation. J Neurosci 2006, 26:10129-10140.

2. Hardy J, Selkoe DJ: The amyloid hypothesis of Alzheimer's disease: progress and problems on the road to therapeutics. Science 2002, 297:353-356.

3. Hong S, Quintero-Monzon O, Ostaszewski BL, Podlisny DR, Cavanaugh WT, Yang T, Holtzman DM, Cirrito JR, Selkoe DJ: Dynamic analysis of amyloid beta-protein in behaving mice reveals opposing changes in ISF versus parenchymal Abeta during age-related plaque formation. J Neurosci 2011, 31:15861-15869.

4. Masters CL, Selkoe DJ: Biochemistry of amyloid beta-protein and amyloid deposits in Alzheimer disease. Cold Spring Harb Perspect Biol Med 2012, 2:a006262.

5. Mucke L, Selkoe DJ: Neurotoxicity of amyloid beta-protein: synaptic and network dysfunction. Cold Spring Harb Perspect Biol Med 2012, 2:a006338.

6. Rice HC, Young-Pearse TL, Selkoe DJ: Systematic evaluation of candidate ligands regulating ectodomain shedding of amyloid precursor protein. Biochemistry 2013, 52:3264-3277.

7. Kimura R, Ohno M: Impairments in remote memory stabilization precede hippocampal synaptic and cognitive failures in 5XFAD Alzheimer mouse model. Neurobiol Dis 2009, 33:229-235.

8. Crouzin N, Baranger K, Cavalier M, Marchalant Y, Cohen-Solal C, Roman FS, Khrestchatisky M, Rivera S, Feron F, Vignes M: Area-specific alterations of synaptic plasticity in the 5XFAD mouse model of Alzheimer's disease: dissociation between somatosensory cortex and hippocampus. PLoS One 2013, 8:e74667.

9. Devi L, Alldred MJ, Ginsberg SD, Ohno M: Sex- and brain region-specific acceleration of beta-amyloidogenesis following behavioral stress in a mouse model of Alzheimer's disease. Mol Brain 2010, 3:34
10. Devi L, Ohno M: Phospho-elF2alpha level is important for determining abilities of BACE1 reduction to rescue cholinergic neurodegeneration and memory defects in 5XFAD mice. PLoS One 2010, 5:e12974.

11. Joyashiki E, Matsuya $Y$, Tohda C: Sominone improves memory impairments and increases axonal density in Alzheimer's disease model mice, 5XFAD. Int J Neurosci 2011, 121:181-190.

12. Jawhar S, Trawicka A, Jenneckens C, Bayer TA, Wirths O: Motor deficits, neuron loss, and reduced anxiety coinciding with axonal degeneration and intraneuronal Abeta aggregation in the 5XFAD mouse model of Alzheimer's disease. Neurobiol Aging 2012, 33:196. e129-140.

13. Devi L, Ohno M: Mechanisms that lessen benefits of beta-secretase reduction in a mouse model of Alzheimer's disease. Trans/ Psychiatry 2013, 3:e284.

14. Girard SD, Baranger K, Gauthier C, Jacquet M, Bernard A, Escoffier G, Marchetti E, Khrestchatisky M, Rivera S, Roman FS: Evidence for early cognitive impairment related to frontal cortex in the 5XFAD mouse model of Alzheimer's disease. J Alzheimers Dis 2013, 33:781-796.

15. Giannoni P, Gaven F, de Bundel D, Baranger K, Marchetti-Gauthier E, Roman FS, Valjent E, Marin P, Bockaert J, Rivera S, Claeysen S: Early administration of RS 67333, a specific 5-HT4 receptor agonist, prevents amyloidogenesis and behavioral deficits in the 5XFAD mouse model of Alzheimer's disease. Front Aging Neurosci 2013, 5:96.

16. Hongpaisan J, Sun MK, Alkon DL: PKC epsilon activation prevents synaptic loss, Abeta elevation, and cognitive deficits in Alzheimer's disease transgenic mice. J Neurosci 2011, 31:630-643.

17. Zhang XM, Cai Y, Xiong K, Cai H, Luo XG, Feng JC, Clough RW, Struble RG, Patrylo PR, Yan XX: Beta-secretase-1 elevation in transgenic mouse models of Alzheimer's disease is associated with synaptic/axonal pathology and amyloidogenesis: implications for neuritic plaque development. Eur J Neurosci 2009, 30:2271-2283.

18. Shao CY, Mirra SS, Sait HB, Sacktor TC, Sigurdsson EM: Postsynaptic degeneration as revealed by PSD-95 reduction occurs after advanced Abeta and tau pathology in transgenic mouse models of Alzheimer's disease. Acta Neuropathol 2011, 122:285-292.

19. Ohno M: Failures to reconsolidate memory in a mouse model of Alzheimer's disease. Neurobiol Learn Mem 2009, 92:455-459.

20. Girard SD, Jacquet M, Baranger K, Migliorati M, Escoffier G, Bernard A, Khrestchatisky M, Feron F, Rivera S, Roman FS, Marchetti E: Onset of hippocampus-dependent memory impairments in 5XFAD transgenic mouse model of Alzheimer's disease. Hippocampus 2014, 24:762-772.

21. Crowe SE, Ellis-Davies GC: Spine pruning in 5xFAD mice starts on basal dendrites of layer 5 pyramidal neurons. Brain Struct Funct 2014, 219:571-580.

22. Buskila Y, Crowe SE, Ellis-Davies GC: Synaptic deficits in layer 5 neurons precede overt structural decay in 5xFAD mice. Neuroscience 2013, 254:152-159.

23. Eimer WA, Vassar R: Neuron loss in the 5XFAD mouse model of Alzheimer's disease correlates with intraneuronal Abeta42 accumulation and Caspase-3 activation. Mol Neurodegener 2013, 8:2.

24. Reddy PH, McWeeney S, Park BS, Manczak M, Gutala RV, Partovi D, Jung Y, Yau V, Searles R, Mori M, Quinn J: Gene expression profiles of transcripts in amyloid precursor protein transgenic mice: up-regulation of mitochondrial metabolism and apoptotic genes is an early cellular change in Alzheimer's disease. Hum Mol Genet 2004, 13:1225-1240.

25. Unger T, Korade Z, Lazarov O, Terrano D, Schor NF, Sisodia SS, Mirnics K: Transcriptome differences between the frontal cortex and hippocampus of wild-type and humanized presenilin-1 transgenic mice. Am J Geriatr Psychiatry 2005, 13:1041-1051.

26. Mirnics K, Korade Z, Arion D, Lazarov O, Unger T, Macioce M, Sabatini M, Terrano D, Douglass KC, Schor NF, Sisodia SS: Presenilin-1-dependent transcriptome changes. J Neurosci 2005, 25:1571-1578.

27. Chen SQ, Cai Q, Shen YY, Wang PJ, Teng GJ, Zhang W, Zang FC: Agerelated changes in brain metabolites and cognitive function in APP/PS1 transgenic mice. Behav Brain Res 2012, 235:1-6.

28. Kim TK, Lee JE, Park SK, Lee KW, Seo JS, Im JY, Kim ST, Lee JY, Kim YH, Lee JK, Han PL: Analysis of differential plaque depositions in the brains of Tg2576 and Tg-APPswe/PS1dE9 transgenic mouse models of Alzheimer disease. Exp Mol Med 2012, 44:492-502.

29. Gatta V, D'Aurora M, Granzotto A, Stuppia L, Sensi SL: Early and sustained altered expression of aging-related genes in young 3xTg-AD mice. Cell death Disease 2014, 5:e1054. 
30. Kim KH, Moon M, Yu SB, Mook-Jung I, Kim Jl: RNA-Seq analysis of frontal cortex and cerebellum from 5XFAD mice at early stage of disease pathology. J Alzheimers Dis 2012, 29:793-808.

31. Bouter $Y$, Kacprowski T, Weissmann R, Dietrich K, Borgers H, Brauss A, Sperling C, Wirths O, Albrecht M, Jensen LR, Kuss AW, Bayer TA: Deciphering the molecular profile of plaques, memory decline and neuron loss in two mouse models for Alzheimer's disease by deep sequencing. Front Aging Neurosci 2014, 6:75

32. Schwarzman AL, Gregori L, Vitek MP, Lyubski S, Strittmatter WJ, Enghilde JJ, Bhasin R, Silverman J, Weisgraber KH, Coyle PK, Michael GZ, Talafous J, Eisenberg M, Saunders AM, Roses AD, Goldaberg D: Transthyretin sequesters amyloid beta protein and prevents amyloid formation. Proc Natl Acad Sci U S A 1994, 91:8368-8372.

33. Choi SH, Leight SN, Lee VM, Li T, Wong PC, Johnson JA, Saraiva MJ, Sisodia SS: Accelerated Abeta deposition in APPswe/PS1deltaE9 mice with hemizygous deletions of TTR (transthyretin). J Neurosci 2007, 27:7006-7010.

34. Li H, Wang B, Wang Z, Guo Q, Tabuchi K, Hammer RE, Sudhof TC, Zheng H: Soluble amyloid precursor protein (APP) regulates transthyretin and Klotho gene expression without rescuing the essential function of APP. Proc Natl Acad Sci U S A 2010, 107:17362-17367.

35. Stein TD, Johnson JA: Lack of neurodegeneration in transgenic mice overexpressing mutant amyloid precursor protein is associated with increased levels of transthyretin and the activation of cell survival pathways. J Neurosci 2002, 22:7380-7388.

36. Kuro-o M, Matsumura $Y$, Aizawa $H$, Kawaguchi $H$, Suga T, Utsugi T, Ohyama Y, Kurabayashi M, Kaname T, Kume E, Iwasaki H, lida A, Shiraki-lida T, Nishikawa S, Nagai R, Nabeshima Yl: Mutation of the mouse klotho gene leads to a syndrome resembling ageing. Nature 1997, 390:45-51.

37. Kurosu H, Yamamoto M, Clark JD, Pastor JV, Nandi A, Gurnani P, McGuinness OP, Chikuda H, Yamaguchi M, Kawaguchi H, Shimomura I, Takayama Y, Herz J, Kahn CR, Rosenblatt KP, Kuro-o M: Suppression of aging in mice by the hormone Klotho. Science 2005, 309:1829-1833.

38. Imura A, Tsuji Y, Murata M, Maeda R, Kubota K, Iwano A, Obuse C, Togashi K, Tominaga M, Kita N, Tomiyama K, lijima J, Nabeshima Y, Fujioka M, Asato R, Tanaka S, Kojima K, Ito J, Nozaki K, Hashimoto N, Ito T, Nishio T, Uchiyama T, Fujimuri T, Nabeshima Y: Alpha-Klotho as a regulator of calcium homeostasis. Science 2007, 316:1615-1618.

39. Xu L, Sapolsky RM, Giffard RG: Differential sensitivity of murine astrocytes and neurons from different brain regions to injury. Exp Neurol 2001, 169:416-424.

40. Zabel MK, Kirsch WM: From development to dysfunction: microglia and the complement cascade in CNS homeostasis. Ageing Res Rev 2013, 12:749-756

41. Mosher Kl, Wyss-Coray T: Microglial dysfunction in brain aging and Alzheimer's disease. Biochem Pharmacol 2014, 88:594-604.

42. Streit WJ, Xue QS: Human CNS immune senescence and neurodegeneration. Curr Opin Immunol 2014, 29C:93-96.

43. Devi L, Ohno M: Genetic reductions of beta-site amyloid precursor protein-cleaving enzyme 1 and amyloid-beta ameliorate impairment of conditioned taste aversion memory in 5XFAD Alzheimer's disease model mice. Eur J Neurosci 2010, 31:110-118.

44. Devi L, Ohno M: Mitochondrial dysfunction and accumulation of the beta-secretase-cleaved C-terminal fragment of APP in Alzheimer's disease transgenic mice. Neurobiol Dis 2012, 45:417-424

45. Terrando N, Monaco C, Ma D, Foxwell BM, Feldmann M, Maze M: Tumor necrosis factor-alpha triggers a cytokine cascade yielding postoperative cognitive decline. Proc Natl Acad Sci U S A 2010, 107:20518-20522.

46. Cibelli M, Fidalgo AR, Terrando N, Ma D, Monaco C, Feldmann M, Takata M Lever IJ, Nanchahal J, Fanselow MS, Maze M: Role of interleukin-1beta in postoperative cognitive dysfunction. Ann Neurol 2010, 68:360-368.

47. Frank-Cannon TC, Alto LT, McAlpine FE, Tansey MG: Does neuroinflammation fan the flame in neurodegenerative diseases? Mol Neurodegener 2009, 4:47.

48. Kadhim HJ, Duchateau J, Sebire G: Cytokines and brain injury: invited review. J Intensive Care Med 2008, 23:236-249.

49. Laird MD, Vender JR, Dhandapani KM: Opposing roles for reactive astrocytes following traumatic brain injury. Neuro-Signals 2008, 16:154-164

50. Morganti-Kossmann MC, Satgunaseelan L, Bye N, Kossmann T: Modulation of immune response by head injury. Injury 2007, 38:1392-1400.
51. Schmidt Ol, Heyde CE, Ertel W, Stahel PF: Closed head injury-an inflammatory disease? Brain Res Brain Res Rev 2005, 48:388-399.

52. Bao F, Shultz SR, Hepburn JD, Omana V, Weaver LC, Cain DP, Brown A: A CD11d monoclonal antibody treatment reduces tissue injury and improves neurological outcome after fluid percussion brain injury in rats. J Neurotrauma 2012, 29:2375-2392.

53. Jana M, Palencia CA, Pahan K: Fibrillar amyloid-beta peptides activate microglia via TLR2: implications for Alzheimer's disease. J Immunol 2008, 181:7254-7262.

54. Hillmann A, Hahn S, Schilling S, Hoffmann T, Demuth HU, Bulic B, Schneider-Axmann T, Bayer TA, Weggen S, Wirths O: No improvement after chronic ibuprofen treatment in the 5XFAD mouse model of Alzheimer's disease. Neurobiol Aging 2012, 33:833. e839-850.

55. McGeer PL, Akiyama H, Itagaki S, McGeer EG: Activation of the classical complement pathway in brain tissue of Alzheimer patients. Neurosci Lett 1989, 107:341-346

56. Fonseca MI, Chu SH, Berci AM, Benoit ME, Peters DG, Kimura Y, Tenner AJ: Contribution of complement activation pathways to neuropathology differs among mouse models of Alzheimer's disease. J Neuroinflammation 2011, 8:4

57. Daborg J, Andreasson U, Pekna M, Lautner R, Hanse E, Minthon L, Blennow K, Hansson O, Zetterberg H: Cerebrospinal fluid levels of complement proteins C3, C4 and CR1 in Alzheimer's disease. J Neural Transm 2012, 119:789-797.

58. Bergamaschini L, Canziani S, Bottasso B, Cugno M, Braidotti P, Agostoni A: Alzheimer's beta-amyloid peptides can activate the early components of complement classical pathway in a C1q-independent manner. Clin Exp Immunol 1999, 115:526-533.

59. Bergamaschini L, Donarini C, Gobbo G, Parnetti L, Gallai V: Activation of complement and contact system in Alzheimer's disease. Mech Ageing Dev 2001, 122:1971-1983.

60. Kulkarni AP, Kellaway LA, Lahiri DK, Kotwal GJ: Neuroprotection from complement-mediated inflammatory damage. Ann N Y Acad Sci 2004, 1035:147-164

61. Zanjani H, Finch CE, Kemper C, Atkinson J, McKeel D, Morris JC, Price JL: Complement activation in very early Alzheimer disease. Alzheimer Dis Assoc Disord 2005, 19:55-66.

62. Crehan H, Hardy J, Pocock J: Microglia, Alzheimer's disease, and complement. Int J Alzheimers Dis 2012, 2012:983640.

63. Togo T, Akiyama H, Iseki E, Kondo H, Ikeda K, Kato M, Oda T, Tsuchiya K, Kosaka K: Occurrence of T cells in the brain of Alzheimer's disease and other neurological diseases. J Neuroimmunol 2002, 124:83-92.

64. Town T, Tan J, Flavell RA, Mullan M: T-cells in Alzheimer's disease. Neruomol Med 2005, 7:255-264.

65. Rodrigues MC, Sanberg PR, Cruz LE, Garbuzova-Davis S: The innate and adaptive immunological aspects in neurodegenerative diseases. J Neuroimmunol 2014, 269:1-8.

66. Baglio F, Saresella M, Preti MG, Cabinio M, Griffanti L, Marventano I, Piancone F, Calabrese E, Nemni R, Clerici M: Neuroinflammation and brain functional disconnection in Alzheimer's disease. Front Aging NeurosCi 2013, 5:81.

67. Shen Y, Yang L, Li R: What does complement do in Alzheimer's disease? Old molecules with new insights. Trans/ Neurodegeneration 2013, 2:21.

68. Veerhuis R: Histological and direct evidence for the role of complement in the neuroinflammation of AD. Curr Alzheimer Res 2011, 8:34-58.

69. Eyles D, Almeras L, Benech P, Patatian A, Mackay-Sim A, McGrath J, Feron F: Developmental vitamin $D$ deficiency alters the expression of genes encoding mitochondrial, cytoskeletal and synaptic proteins in the adult rat brain. J Steroid Biochem Mol Biol 2007, 103:538-545.

70. Barrey E, Mucher E, Jeansoule N, Larcher T, Guigand L, Herszberg B, Chaffaux S, Guerin G, Mata X, Benech P, Canale M, Alibert O, Maltere P, Gidrol X: Gene expression profiling in equine polysaccharide storage myopathy revealed inflammation, glycogenesis inhibition, hypoxia and mitochondrial dysfunctions. BMC Vet Res 2009, 5:29.

71. Terrier B, Joly F, Vazquez T, Benech P, Rosenzwajg M, Carpentier W, Garrido M, Ghillani-Dalbin P, Klatzmann D, Cacoub P, Saadoun D: Expansion of functionally anergic CD21-/low marginal zone-like B cell clones in hepatitis $C$ virus infection-related autoimmunity. J Immunol 2011, 187:6550-6563.

72. Barrey E, Jayr L, Mucher E, Gospodnetic S, Joly F, Benech P, Alibert O, Gidrol $X$, Mata X, Vaiman A, Guerin G: Transcriptome analysis of muscle in horses 
suffering from recurrent exertional rhabdomyolysis revealed energetic pathway alterations and disruption in the cytosolic calcium regulation. Anim Genet 2012, 43:271-281.

73. Mille-Hamard L, Billat VL, Henry E, Bonnamy B, Joly F, Benech P, Barrey E: Skeletal muscle alterations and exercise performance decrease in erythropoietin-deficient mice: a comparative study. BMC Med Genet 2012, 5:29.

74. Almeras L, Eyles D, Benech P, Laffite D, Villard C, Patatian A, Boucraut J, Mackay-Sim A, McGrath J, Feron F: Developmental vitamin D deficiency alters brain protein expression in the adult rat: implications for neuropsychiatric disorders. Proteomics 2007, 7:769-780.

75. Kawanokuchi J, Mizuno T, Takeuchi H, Kato H, Wang J, Mitsuma N, Suzumura A: Production of interferon-gamma by microglia. Mult Scler 2006, 12:558-564.

76. Chakrabarty P, Ceballos-Diaz C, Beccard A, Janus C, Dickson D, Golde TE, Das P: IFN-gamma promotes complement expression and attenuates amyloid plaque deposition in amyloid beta precursor protein transgenic mice. J Immunol 2010, 184:5333-5343.

77. Zhang J, Ke KF, Liu Z, Qiu YH, Peng YP: Th17 cell-mediated neuroinflammation is involved in neurodegeneration of abeta1-42-induced Alzheimer's disease model rats. PLoS One 2013, 8:e75786.

78. Lynch MA: The impact of neuroimmune changes on development of amyloid pathology; relevance to Alzheimer's disease. Immunology 2013, 141:292-301.

79. Kook SY, Hong HS, Moon M, Ha CM, Chang S, Mook-Jung I: Abeta(1)(-)(4) (2)-RAGE interaction disrupts tight junctions of the blood-brain barrier via $\mathrm{Ca}(2)(+)$-calcineurin signaling. J Neurosci 2012, 32:8845-8854

80. Browne TC, McQuillan K, McManus RM, O'Reilly JA, Mills KH, Lynch MA IFN-gamma Production by amyloid beta-specific Th1 cells promotes microglial activation and increases plaque burden in a mouse model of Alzheimer's disease. J Immunol 2013, 190:2241-2251.

81. O'Keefe GM, Nguyen VT, Benveniste EN: Regulation and function of class II major histocompatibility complex, CD40, and B7 expression in macrophages and microglia: Implications in neurological diseases. J Neurovirol 2002, 8:496-512.

82. Tooyama I, Kimura H, Akiyama H, McGeer PL: Reactive microglia express class I and class II major histocompatibility complex antigens in Alzheimer's disease. Brain Res 1990, 523:273-280.

83. Bryan KJ, Zhu X, Harris PL, Perry G, Castellani RJ, Smith MA, Casadesus G: Expression of CD74 is increased in neurofibrillary tangles in Alzheimer's disease. Mol Neurodegener 2008, 3:13.

84. Gore Y, Starlets D, Maharshak N, Becker-Herman S, Kaneyuki U, Leng L, Bucala R, Shachar I: Macrophage migration inhibitory factor induces $B$ cell survival by activation of a CD74-CD44 receptor complex. J Biol Chem 2008, 283:2784-2792.

85. Matsuda S, Matsuda Y, D'Adamio L: CD74 interacts with APP and suppresses the production of Abeta. Mol Neurodegener 2009, 4:41.

86. Bekpen C, Xavier RJ, Eichler EE: Human IRGM gene "to be or not to be". Semin Immunopathol 2010, 32:437-444.

87. Taylor GA, Feng CG, Sher A: p47 GTPases: regulators of immunity to intracellular pathogens. Nat Rev Immunol 2004, 4:100-109.

88. He S, Wang C, Dong H, Xia F, Zhou H, Jiang X, Pei C, Ren H, Li H, Li R, Xu H: Immune-related GTPase M (IRGM1) regulates neuronal autophagy in a mouse model of stroke. Autophagy 2012, 8:1621-1627.

89. Wang C, Wang C, Dong H, Wu XM, Wang C, Xia F, Li G, Jia X, He S, Jiang X, $\mathrm{Li} \mathrm{H}$, Xu H: Immune-related GTPase Irgm1 exacerbates experimental auto-immune encephalomyelitis by promoting the disruption of blood-brain barrier and blood-cerebrospinal fluid barrier. Mol Immunol 2013, 53:43-51.

90. Feng CG, Weksberg DC, Taylor GA, Sher A, Goodell MA: The p47 GTPase Lrg-47 (Irgm1) links host defense and hematopoietic stem cell proliferation. Cell Stem Cell 2008, 2:83-89.

91. Zhao YO, Khaminets A, Hunn JP, Howard JC: Disruption of the Toxoplasma gondii parasitophorous vacuole by IFNgamma-inducible immunityrelated GTPases (IRG proteins) triggers necrotic cell death. PLOS Pathog 2009, 5:e1000288.

92. Xu H, Wu ZY, Fang F, Guo L, Chen D, Chen JX, Stern D, Taylor GA, Jiang H, Yan SS: Genetic deficiency of Irgm1 (LRG-47) suppresses induction of experimental autoimmune encephalomyelitis by promoting apoptosis of activated CD4+ T cells. FASEB J 2010, 24:1583-1592.
93. Henry SC, Daniell XG, Burroughs AR, Indaram M, Howell DN, Coers J, Starnbach MN, Hunn JP, Howard JC, Feng CG, Sher A, Taylor GA: Balance of Irgm protein activities determines IFN-gamma-induced host defense. J Leukoc Biol 2009, 85:877-885.

94. Hunn JP, Howard JC: The mouse resistance protein Irgm1 (LRG-47): a regulator or an effector of pathogen defense? PLoS Pathog 2010, 6:e1001008.

95. Sardiello M, Palmieri M, di Ronza A, Medina DL, Valenza M, Gennarino VA, Di Malta C, Donaudy F, Embrione V, Polishchuk RS, Banfi S, Parenti G, Cattaneo E, Ballabio A: A gene network regulating lysosomal biogenesis and function. Science 2009, 325:473-477.

96. Settembre C, Di Malta C, Polito VA, Garcia Arencibia M, Vetrini F, Erdin S, Erdin SU, Huynh T, Medina D, Colella P, Sardiello M, Rubinsztein DC, Ballabio A: TFEB links autophagy to lysosomal biogenesis. Science 2011, 332:1429-1433.

97. Zhang X, Garbett K, Veeraraghavalu K, Wilburn B, Gilmore R, Mirnics K, Sisodia SS: A role for presenilins in autophagy revisited: normal acidification of lysosomes in cells lacking PSEN1 and PSEN2. J Neurosci 2012, 32:8633-8648.

98. Li Y, Xu C, Schubert D: The up-regulation of endosomal-lysosomal components in amyloid beta-resistant cells. J Neurochem 1999, 73:1477-1482.

99. Pasternak SH, Callahan JW, Mahuran DJ: The role of the endosomal/ lysosomal system in amyloid-beta production and the pathophysiology of Alzheimer's disease: reexamining the spatial paradox from a lysosomal perspective. J Alzheimers Dis 2004, 6:53-65.

100. Kandalepas PC, Sadleir KR, Eimer WA, Zhao J, Nicholson DA, Vassar R: The Alzheimer's beta-secretase BACE1 localizes to normal presynaptic terminals and to dystrophic presynaptic terminals surrounding amyloid plaques. Acta Neuropathol 2013, 126:329-352

101. Avrahami L, Farfara D, Shaham-Kol M, Vassar R, Frenkel D, Eldar-Finkelman $H$ : Inhibition of glycogen synthase kinase-3 ameliorates beta-amyloid pathology and restores lysosomal acidification and mammalian target of rapamycin activity in the Alzheimer disease mouse model: in vivo and in vitro studies. J Biol Chem 2013, 288:1295-1306.

102. Nixon RA, Cataldo AM, Mathews PM: The endosomal-lysosomal system of neurons in Alzheimer's disease pathogenesis: a review. Neurochem Res 2000, 25:1161-1172.

103. Gobin SJ, Peijnenburg A, Keijsers V, van den Elsen PJ: Site alpha is crucial for two routes of IFN gamma-induced MHC class I transactivation: the ISRE-mediated route and a novel pathway involving CIITA. Immunity 1997, 6:601-611

104. Muhlethaler-Mottet A, Di Berardino W, Otten LA, Mach B: Activation of the MHC class II transactivator CIITA by interferon-gamma requires cooperative interaction between Stat1 and USF-1. Immunity 1998, 8:157-166.

105. Driggers PH, Ennist DL, Gleason SL, Mak WH, Marks MS, Levi BZ, Flanagan JR, Appella E, Ozato K: An interferon gamma-regulated protein that binds the interferon-inducible enhancer element of major histocompatibility complex class I genes. Proc Natl Acad Sci U S A 1990, 87:3743-3747.

106. Weisz A, Kirchhoff $S$, Levi BZ: IFN consensus sequence binding protein (ICSBP) is a conditional repressor of IFN inducible promoters. Int Immunol 1994, 6:1125-1131.

107. Perez C, Wietzerbin J, Benech PD: Two cis-DNA elements involved in myeloid-cell-specific expression and gamma interferon (IFN-gamma) activation of the human high-affinity Fc gamma receptor gene: a novel IFN regulatory mechanism. Mol Cell Biol 1993, 13:2182-2192.

108. Masuda T, Tsuda M, Yoshinaga R, Tozaki-Saitoh H, Ozato K, Tamura T, Inoue K: IRF8 is a critical transcription factor for transforming microglia into a reactive phenotype. Cell Reports 2012, 1:334-340.

109. Tamura T, Yanai H, Savitsky D, Taniguchi T: The IRF family transcription factors in immunity and oncogenesis. Annu Rev Immunol 2008, 26:535-584.

110. Wang $H$, Morse HC 3rd: IRF8 regulates myeloid and B lymphoid lineage diversification. Immunol Res 2009, 43:109-117.

111. Marquis JF, Kapoustina O, Langlais D, Ruddy R, Dufour CR, Kim BH, MacMicking JD, Giguere V, Gros P: Interferon regulatory factor 8 regulates pathways for antigen presentation in myeloid cells and during tuberculosis. PLoS Genet 2011, 7:e1002097.

112. Berghout J, Langlais D, Radovanovic I, Tam M, MacMicking JD, Stevenson MM, Gros P: Irf8-regulated genomic responses drive pathological inflammation during cerebral malaria. PLOS Pathog 2013, 9:e1003491. 
113. Ju XS, Ruau D, Jantti P, Sere K, Becker C, Wiercinska E, Bartz C, Erdmann B, Dooley S, Zenke M: Transforming growth factor beta1 up-regulates interferon regulatory factor 8 during dendritic cell development. Eur $J$ Immunol 2007, 37:1174-1183.

114. Suzumura A, Sawada M, Yamamoto H, Marunouchi T: Transforming growth factor-beta suppresses activation and proliferation of microglia in vitro. J Immunol 1993, 151:2150-2158.

115. Frei $K$, Lins $H$, Schwerdel $C$, Fontana $A$ : Antigen presentation in the central nervous system. The inhibitory effect of IL-10 on MHC class II expression and production of cytokines depends on the inducing signals and the type of cell analyzed. J Immunol 1994, 152:2720-2728.

116. Qin L, Crews FT: NADPH oxidase and reactive oxygen species contribute to alcohol-induced microglial activation and neurodegeneration. J Neuroinflammation 2012, 9:5.

117. Qin L, Liu Y, Hong JS, Crews FT: NADPH oxidase and aging drive microglial activation, oxidative stress, and dopaminergic neurodegeneration following systemic LPS administration. Glia 2013, 61:855-868.

118. Pratico D, Uryu K, Leight S, Trojanoswki JQ, Lee VM: Increased lipid peroxidation precedes amyloid plaque formation in an animal model of Alzheimer amyloidosis. J Neurosci 2001, 21:4183-4187.

119. Xie H, Guan J, Borrelli LA, Xu J, Serrano-Pozo A, Bacskai BJ: Mitochondrial alterations near amyloid plaques in an Alzheimer's disease mouse model. J Neurosci 2013, 33:17042-17051.

120. Hong I, Kang T, Yoo Y, Park R, Lee J, Lee S, Kim J, Song B, Kim SY, Moon M, Yun KN, Kim JY, Mook-Jung I, Park YM, Choi S: Quantitative proteomic a nalysis of the hippocampus in the 5XFAD mouse model at early stages of Alzheimer's disease pathology. J Alzheimers Dis 2013, 36:321-334.

121. Errante PR, Frazao JB, Condino-Neto A: The use of interferon-gamma therapy in chronic granulomatous disease. Recent Patents Anti-infective drug Dis 2008, 3:225-230

122. Manea A, Tanase LI, Raicu M, Simionescu M: Jak/STAT signaling pathway regulates nox 1 and nox4-based NADPH oxidase in human aortic smooth muscle cells. Arterioscler Thromb Vasc Biol 2010, 30:105-112.

123. Marchi LF, Sesti-Costa R, Ignacchiti MD, Chedraoui-Silva S, Mantovani B: In vitro activation of mouse neutrophils by recombinant human interferongamma: increased phagocytosis and release of reactive oxygen species and pro-inflammatory cytokines. Int Immunopharmacol 2014, 18:228-235.

124. Matute JD, Arias AA, Dinauer MC, Patino PJ: p40phox: the last NADPH oxidase subunit. Blood Cells Mol Dis 2005, 35:291-302.

125. Tian W, Li XJ, Stull ND, Ming W, Suh Cl, Bissonnette SA, Yaffe MB, Grinstein S, Atkinson SJ, Dinauer MC: Fc gamma R-stimulated activation of the NADPH oxidase: phosphoinositide-binding protein p40phox regulates NADPH oxidase activity after enzyme assembly on the phagosome. Blood 2008, 112:3867-3877.

126. Utomo A, Cullere X, Glogauer M, Swat W, Mayadas TN: Vav proteins in neutrophils are required for FcgammaR-mediated signaling to Rac GTPases and nicotinamide adenine dinucleotide phosphate oxidase component p40(phox). J Immunol 2006, 177:6388-6397.

127. Shimohama S, Tanino H, Kawakami N, Okamura N, Kodama H, Yamaguchi T, Hayakawa T, Nunomura A, Chiba S, Perry G, Smith MA, Fujimoto S: Activation of NADPH oxidase in Alzheimer's disease brains. Biochem Biophys Res Commun 2000, 273:5-9.

128. Abramov AY, Canevari L, Duchen MR: Beta-amyloid peptides induce mitochondrial dysfunction and oxidative stress in astrocytes and death of neurons through activation of NADPH oxidase. J Neurosci 2004, 24:565-575.

129. Ponomarev ED, Shriver LP, Dittel BN: CD40 expression by microglial cells is required for their completion of a two-step activation process during central nervous system autoimmune inflammation. J Immunol 2006, 176:1402-1410.

130. Wojtera M, Sobow T, Kloszewska I, Liberski PP, Brown DR, Sikorska B: Expression of immunohistochemical markers on microglia in CreutzfeldtJakob disease and Alzheimer's disease: morphometric study and review of the literature. Folia Neuropathol 2012, 50:74-84.

131. Walker FR, Nilsson M, Jones K: Acute and chronic stress-induced disturbances of microglial plasticity, phenotype and function. Curr Drug Targets 2013, 14:1262-1276

132. Peress NS, Fleit HB, Perillo E, Kuljis R, Pezzullo C: Identification of Fc gamma $\mathrm{RI}, \mathrm{II}$ and III on normal human brain ramified microglia and on microglia in senile plaques in Alzheimer's disease. J Neuroimmunol 1993, 48:71-79.
133. Dorseuil O, Reibel L, Bokoch GM, Camonis J, Gacon G: The Rac target NADPH oxidase p67phox interacts preferentially with Rac2 rather than Rac1. J Biol Chem 1996, 271:83-88.

134. Dorseuil O, Vazquez A, Lang P, Bertoglio J, Gacon G, Leca G: Inhibition of superoxide production in $B$ lymphocytes by rac antisense oligonucleotides. J Biol Chem 1992, 267:20540-20542.

135. Rogers J, Lue LF: Microglial chemotaxis, activation, and phagocytosis of amyloid beta-peptide as linked phenomena in Alzheimer's disease. Neurochem Int 2001, 39:333-340.

136. Fiala M, Lin J, Ringman J, Kermani-Arab V, Tsao G, Patel A, Lossinsky AS, Graves MC, Gustavson A, Sayre J, Sofroni E, Suarez T, Chiapelli F, Bernard G: Ineffective phagocytosis of amyloid-beta by macrophages of Alzheimer's disease patients. J Alzheimers Dis 2005, 7:221-232. discussion 255-262.

137. Koenigsknecht J, Landreth G: Microglial phagocytosis of fibrillar betaamyloid through a beta1 integrin-dependent mechanism. J Neurosci 2004, 24:9838-9846.

138. Liu Y, Walter S, Stagi M, Cherny D, Letiembre M, Schulz-Schaeffer W, Heine H, Penke B, Neumann H, Fassbender K: LPS receptor (CD14): a receptor for phagocytosis of Alzheimer's amyloid peptide. Brain 2005, 128:1778-1789.

139. Luo J, Elwood F, Britschgi M, Villeda S, Zhang H, Ding Z, Zhu L, Alabsi H, Getachew R, Narasimhan R, Wabl R, Fainberg N, James ML, Wong G, Relton J, Gambhir SS, Pollard JW, Wyss-Coray T: Colony-stimulating factor 1 receptor (CSF1R) signaling in injured neurons facilitates protection and survival. J Exp Med 2013, 210:157-172.

140. Neumann H, Daly MJ: Variant TREM2 as risk factor for Alzheimer's disease. N Engl J Med 2013, 368:182-184.

141. Guerreiro R, Wojtas A, Bras J, Carrasquillo M, Rogaeva E, Majounie E, Cruchaga C, Sassi C, Kauwe JS, Lupton MK, Ryten M, Brown K, Lowe J, Ridge PG, Hammer MB, Wakutani Y, Hazrati L, Proitsi P, Newhouse S, Lohmann E, Erginel-Unaltuna N, Medway C, Hanagasi H, Troakes C, Gurvit H, Bilgic B, AlSarraj S, Benitez B, Cooper B, Carrell D, et al: TREM2 variants in Alzheimer's disease. N Engl J Med 2013, 368:117-127.

142. Jonsson T, Stefansson H, Steinberg S, Jonsdottir I, Jonsson PV, Snaedal J, Bjornsson S, Huttenlocher J, Levey Al, Lah JJ, Rujescu D, Hampel H, Giegling I, Andreassen OA, Engedal K, Ulstein I, Djurovic S, Ibrahim-Verbaas C, Hofman A, Ikram MA, van Duijn CM, Thorsteinsdottir U, Kong A Stefansson K: Variant of TREM2 associated with the risk of Alzheimer's disease. N Engl J Med 2013, 368:107-116.

143. Takahashi K, Prinz M, Stagi M, Chechneva O, Neumann H: TREM2transduced myeloid precursors mediate nervous tissue debris clearance and facilitate recovery in an animal model of multiple sclerosis. PLoS Med 2007, 4:e124.

144. Piccio L, Buonsanti C, Mariani M, Cella M, Gilfillan S, Cross AH, Colonna M, Panina-Bordignon P: Blockade of TREM-2 exacerbates experimental autoimmune encephalomyelitis. Eur J Immunol 2007, 37:1290-1301.

145. Frank S, Burbach GJ, Bonin M, Walter M, Streit W, Bechmann I, Deller T: TREM2 is upregulated in amyloid plaque-associated microglia in aged APP23 transgenic mice. Glia 2008, 56:1438-1447.

146. Hamerman JA, Tchao NK, Lowell CA, Lanier LL: Enhanced Toll-like receptor responses in the absence of signaling adaptor DAP12. Nat Immunol 2005, 6:579-586.

147. Hamerman JA, Jarjoura JR, Humphrey MB, Nakamura MC, Seaman WE, Lanier LL: Cutting edge: inhibition of TLR and FCR responses in macrophages by triggering receptor expressed on myeloid cells (TREM)-2 and DAP12. J Immunol 2006, 177:2051-2055.

148. Vardy ER, Rice PJ, Bowie PC, Holmes JD, Grant PJ, Hooper NM: Increased circulating insulin-like growth factor-1 in late-onset Alzheimer's disease. J Alzheimers Dis 2007, 12:285-290.

149. Freude S, Schilbach K, Schubert M: The role of IGF-1 receptor and insulin receptor signaling for the pathogenesis of Alzheimer's disease: from model organisms to human disease. Curr Alzheimer Res 2009, 6:213-223.

150. Pang Y, Zheng B, Campbell LR, Fan LW, Cai Z, Rhodes PG: IGF-1 can either protect against or increase LPS-induced damage in the developing rat brain. Pediatr Res 2010, 67:579-584.

151. Ryu BR, Ko HW, Jou I, Noh JS, Gwag BJ: Phosphatidylinositol 3-kinasemediated regulation of neuronal apoptosis and necrosis by insulin and IGF-I. J Neurobiol 1999, 39:536-546.

152. Davila D, Torres-Aleman I: Neuronal death by oxidative stress involves activation of $\mathrm{FOXO} 3$ through a two-arm pathway that activates stress kinases and attenuates insulin-like growth factor I signaling. Mol Biol Cell 2008, 19:2014-2025. 
153. Madathil SK, Carlson SW, Brelsfoard JM, Ye P, D'Ercole AJ, Saatman KE: Astrocyte-Specific Overexpression of Insulin-Like Growth Factor-1 Protects Hippocampal Neurons and Reduces Behavioral Deficits following Traumatic Brain Injury in Mice. PLoS One 2013, 8:e67204.

154. Repovic P, Benveniste EN: Prostaglandin E2 is a novel inducer of oncostatin-M expression in macrophages and microglia. J Neurosci 2002, 22:5334-5343.

155. Weiss TW, Samson AL, Niego B, Daniel PB, Medcalf RL: Oncostatin M is a neuroprotective cytokine that inhibits excitotoxic injury in vitro and in vivo. FASEB I 2006, 20:2369-2371.

156. Ganesh K, Das A, Dickerson R, Khanna S, Parinandi NL, Gordillo GM, Sen CK, Roy S: Prostaglandin $\mathrm{E}(2)$ induces oncostatin $\mathrm{M}$ expression in human chronic wound macrophages through Axl receptor tyrosine kinase pathway. J Immunol 2012, 189:2563-2573.

157. Park KW, Nozell SE, Benveniste EN: Protective role of STAT3 in NMDA and glutamate-induced neuronal death: negative regulatory effect of SOCS3. PLoS One 2012, 7:e50874

158. Sleegers K, Brouwers N, Van Broeckhoven C: Role of progranulin as a biomarker for Alzheimer's disease. Biomark Med 2010, 4:37-50.

159. Pickford F, Marcus J, Camargo LM, Xiao Q, Graham D, Mo JR, Burkhardt M, Kulkarni V, Crispino J, Hering H, Hutton M: Progranulin is a chemoattractant for microglia and stimulates their endocytic activity. Am J Pathol 2011, 178:284-295.

160. Tang W, Lu Y, Tian QY, Zhang Y, Guo FJ, Liu GY, Syed NM, Lai Y, Lin EA, Kong L, Su J, Yin F, Ding AH, Zanin-Zhorov A, Dustin ML, Tao J, Craft J, Yin Z, Feng JQ, Abramson SB, Yu XP, Liu CJ: The growth factor progranulin binds to TNF receptors and is therapeutic against inflammatory arthritis in mice. Science 2011, 332:478-484.

161. Zhu J, Nathan C, Jin W, Sim D, Ashcroft GS, Wahl SM, Lacomis L, ErdjumentBromage $H$, Tempst $P$, Wright CD, Ding A: Conversion of proepithelin to epithelins: roles of SLPI and elastase in host defense and wound repair. Cell 2002, 111:867-878.

162. Okura H, Yamashita S, Ohama T, Saga A, Yamamoto-Kakuta A, Hamada Y, Sougawa N, Ohyama R, Sawa Y, Matsuyama A: HDL/apolipoprotein A-I binds to macrophage-derived progranulin and suppresses its conversion into proinflammatory granulins. J Atheroscler Thromb 2010, 17:568-577.

163. Bhattacharya S, Haertel C, Maelicke A, Montag D: Galantamine slows down plaque formation and behavioral decline in the SXFAD mouse model of Alzheimer's disease. PloS One 2014, 9:e89454.

164. ArrayExpress database. [www.ebi.ac.uk/arrayexpress]

165. Ingenuity Systems. [www.ingenuity.com]

166. Prediguard. [www.laboratoire-genex.fr]

doi:10.1186/1750-1326-9-33

Cite this article as: Landel et al:: Temporal gene profiling of the 5XFAD transgenic mouse model highlights the importance of microglial activation in Alzheimer's disease. Molecular Neurodegeneration 2014 9:33.

\section{Submit your next manuscript to BioMed Central and take full advantage of:}

- Convenient online submission

- Thorough peer review

- No space constraints or color figure charges

- Immediate publication on acceptance

- Inclusion in PubMed, CAS, Scopus and Google Scholar

- Research which is freely available for redistribution 